\title{
Stratigraphic position and sedimentary environment of Late Pleistocene deposits along the cliffed coast of the middle part of the Polish Baltic coast
}

\author{
Dariusz KRZYSZKOWSKI ${ }^{1}$ and Dorota KOSZKA-MAROŃN ${ }^{2, *}$ \\ 1 University of Wrocław, Institute of Geography and Regional Development, pl. Uniwersytecki 1, 50-137 Wrocław, Poland \\ 2 Polish Geological Institute - National Research Institute, Marine Geology Branch, Kościerska 5, 80-328 Gdańsk, Poland
}

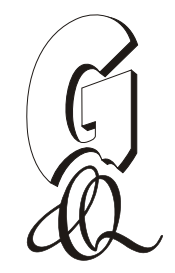

\begin{abstract}
Krzyszkowski, D., Koszka-Maroń, D., 2018. Stratigraphic position and sedimentary environment of Late Pleistocene deposits along the cliffed coast of the middle part of the Polish Baltic coast. Geological Quarterly, 62 (1): 48-68, doi: 10.7306/gq. 1392

Associate Editor - Wojciech Granoszewski
\end{abstract}

The study was carried out in the wall of a cliff that formed as a result of erosional cutting in the western foreland of a moraine landform from the Pomeranian and Gardno phases (Upper Plenivistulian, Rowy-Ustka clifs; northern Poland). Individual lithostratigraphic units have been documented: glaciofluvial delta deposits, Poddabie Till, lacustrine-glacial Wytowno Formation (consisting of three facies: deltaic, lower diamicton, and upper diamicton), lacustrine deposits of the Orzechowo Formation with a thick peat layer, and aeolian series at the cliff crest. The Wytowno Formation deposits include the following lithologies: medium-grained sands, fine-grained sands, muddy sands, muds, silty clays, clays, varved clays, fine-grained multi-fraction deposits, and tills (Dębina Till). Very high inclination of the strata is the result of glaciodynamic deformation. The deposits were accumulated in a proglacial lake. They are characterized by mud and clay as well as sand and sand-muddy lithofacies. The vastness of the water body is evidenced by a considerable size of the delta, and by massive structures of the clay layers.

Key words: cliff, geological structure, stratigraphy, petrography, Baltic coast.

\section{INTRODUCTION}

An important place in the landscape of the geomorphologically variable coastal zone of the Baltic Sea is occupied by the magnificent cliffs extending between Dębina and Poddąbie, which are part of the Rowy-Ustka cliffs, and are among Poland's coasts most affected by sea action. The inland coastal zone between Dębina and Ustka is interesting in terms of its geology and geomorphology. It is an area where the coast represented by the Pleistocene plateau edge meets the Holocene spit-dune coast. A number of geodynamic processes take place in this area, triggered by sea-waters, ground and surface waters, and unstable shoreline conditions. The section of the cliff under study is a natural landform, highly diverse, and free of any man-made hydraulic structures. The cliff is situated between $16^{\circ} 59^{\prime} 30^{\prime \prime} \mathrm{E}$ and $17^{\circ} 00^{\prime} 00^{\prime \prime} \mathrm{E}$, and between $54^{\circ} 38^{\prime} 00^{\prime \prime} \mathrm{N}$ and $54^{\circ} 38^{\prime} 15^{\prime \prime} \mathrm{N}$, along the kilometres $222.5-227.0$ of coastal chainage (Fig. 1).

The cliff sections are located along the axis of a moraine of the Gardno Phase, and on the moraine plateau in its western

*Corresponding author, e-mail: dkos@pgi.gov.pl

Received: February 28, 2017; accepted: October 11, 2017; first published online: December 13, 2017 foreland. The research, including description of sites 1-13, was carried out between 225.5-227.0 km (Fig. 2), and detailed analysis was conducted in three exposures in the cliff wall between 222.5-223 km (Fig. 3).

A thorough inventory of the lithologically highly variable Pleistocene deposits, exposed in the cliff walls over a distance of $1.5 \mathrm{~km}$ along the Polish coast, has allowed identification of glacial and interglacial series of various ages, which enabled updating the stratigraphic scheme of the upper Pleistocene for the middle coast of the Baltic Sea. The main goal of the study was establishing the conditions and depositional environment, based on lithostratigraphic and lithofacies characteristics of the sediments that have never been characterized in any other scientific reports. These were the basis for identification of the origin and stratigraphy of the deposits interpreted so far as glacigenic and representing the LGM (Last Glacial Maximum). In addition, the paper provides more comprehensive interpretation of deposits accumulated during interglacial periods and outlined in previous studies.

\section{GEOLOGICAL SETTING}

In regional geology terms, the study area is located in the Łeba Elevation, which is a prominent structural-tectonic unit included in the southern flank of the Baltic Shield (Mojski et al., 1978). The base-Quaternary surface relief is highly variable be- 


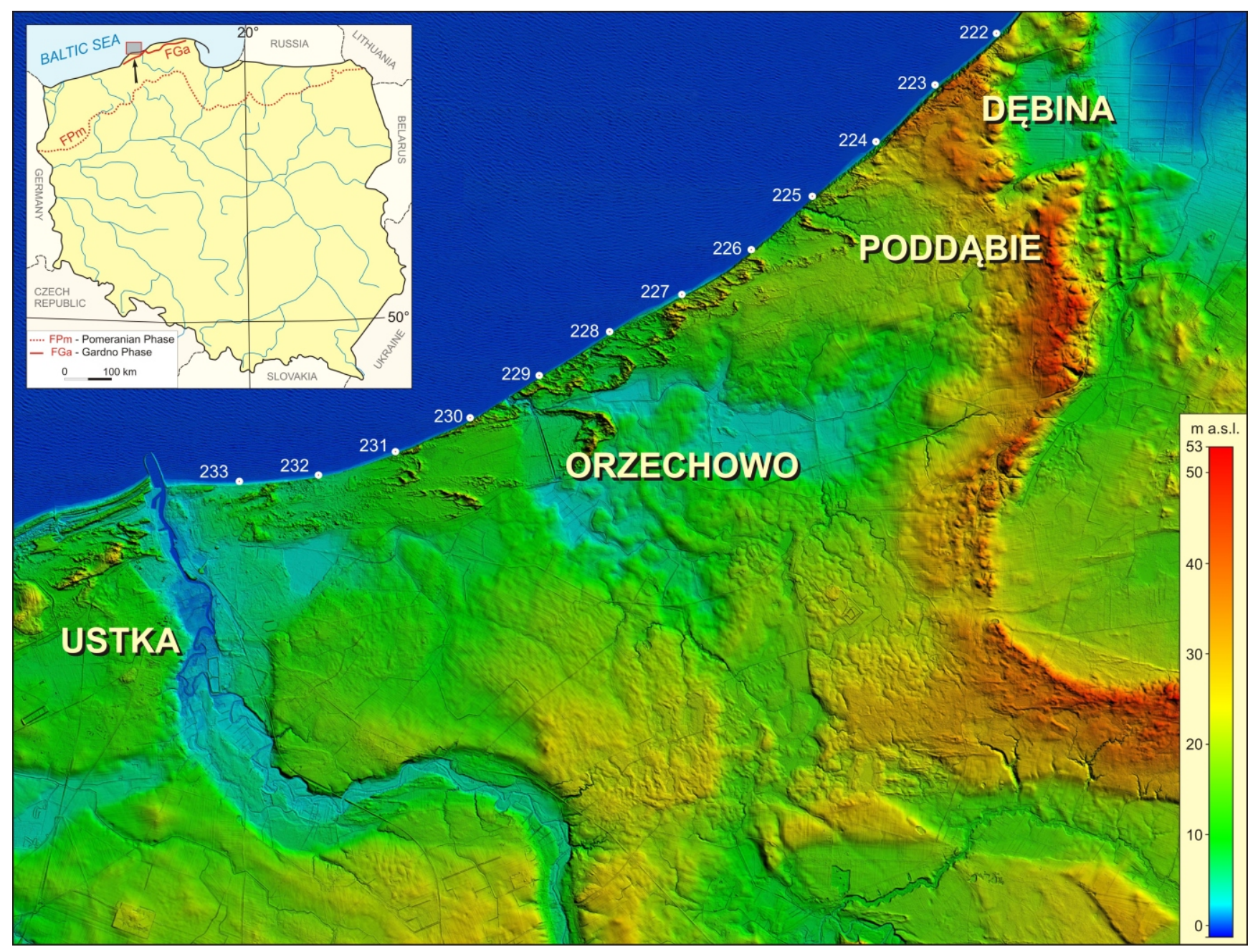

Fig. 1. Location of the study area

cause the sub-Quaternary basement was affected by erosion of melt waters, glacial exaration processes, and glaciotectonic processes. The thickness of the Quaternary deposits varies from $\sim 40 \mathrm{~m}$ in Ustka to $130 \mathrm{~m}$ east of the Łupawa River mouth (Tomczak, 1995).

Important elements of the cliffed coast between Dębina and Ustka are flow tills and glaciolimnic deposits accumulated during the late Vistulian. The pattern of strata is highly complex in many areas, locally indecipherable. Their eastern outcrops are frequently covered with colluvial deposits of variable thickness which is an additional obstacle for geological mapping (Dobrzyński, 1996).

The studies of Petelski (1975, 1976, 1985, 1998, 2011), Subotowicz (1982), Dziedzic (1990), Racinowski et al. (1992, 1993a, b), Dobrzyński (1994, 1996), Dziedzic et al. (1994), Krzyszkowski et al. (1998), Jasiewicz (1998, 1999, 2001a, b, 2005,2007 ) and Jasiewicz et al. (2005) have shown variability of the geological structure of the area, and allowed subdividing the coastal zone into individual sections, providing details to the current knowledge.

The whole cliffed coast between Dębina and Ustka is divided into two parts with respect to the geological structure. Its eastern part, between Dębina and Orzechowo (221.200-228.600 km chainage), includes the cliffed shoreline cutting an end moraine of the Gardno ice sheet lobe. The western part, between Orzechowo and Ustka (228.600-231.300 km chainage), exposes thin Pleistocene deposits capped by dunes. The top of the Pleistocene descends westwards (Petelski, 1975, 1976).

In the eastern region, from Dębina to Poddąbie, two till beds, glaciolimnic silty-clay deposits with glaciofluvial sand-gravelly material, are exposed. The lower bed is represented by highly compact glacial till, brownish in colour, with numerous boulders up to $0.7 \mathrm{~m}$ across. This till predates the Gardno Phase. At the top, it is truncated by the other till bed associated with the advancing Gardno Phase ice sheet. This bed is represented by brown sandy till that locally contains interbeds of loamy sands and gravels (Petelski, 1975). In the exposed cliff slope, both till beds dip eastwards.

The brown till is separated from the brownish till by a zone of glaciodynamic deformation and glaciofluvial sands (Petelski, 1976, 1985; Jasiewicz, 1998, 2001a, 2005, 2007; Jasiewicz et al., 2005). The glaciodynamic disturbance and deformations developed at the contact between the bedrock and the ice sheet base. Deformational structures found at the base of the brown till are a good indicator of ice sheet movement direction. The thickness of the glaciodynamic deformation zone ranges from 1 to $8 \mathrm{~m}$. It consists of two, locally three deformed till beds separated by muds and variously grained, coarse and fine sands. The muds of the glaciodynamic deformation zone reveal diapiric and fold structures (Petelski, 1975, 1998; Jasiewicz, 1998, 2001a, 2005, 2007). 

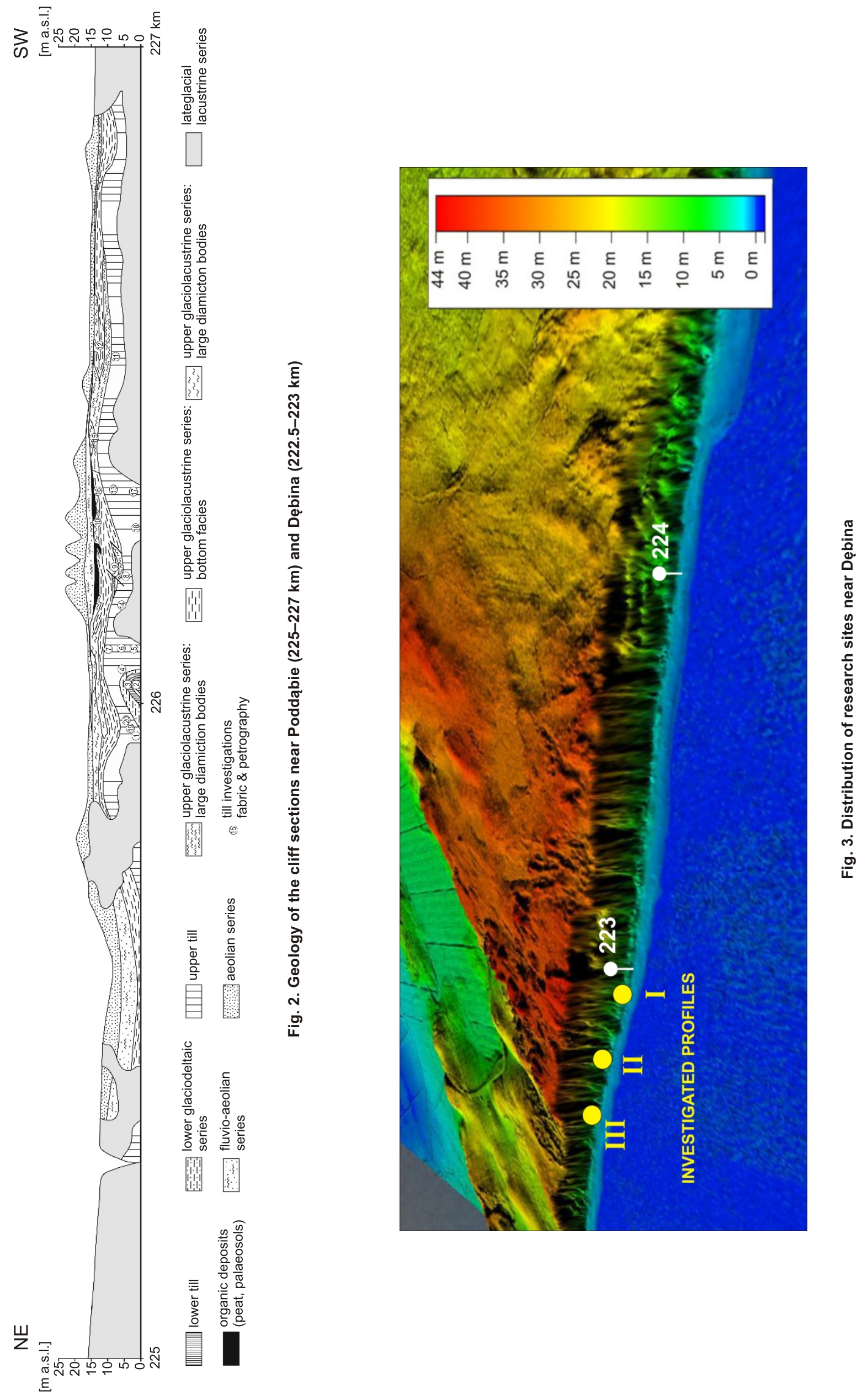
The lithostratigraphy of the Gardno end moraine structure includes five till levels named: Stojcino Till, Poddąbie Till, Dębina Till - upper and lower member, and Gardno till (Jasiewicz et al., 2005).

The first one, Stojcino Till, was identified in four positions: as the basement of the ice-dammed lake sediments associated with the recession of Warta Glaciation or transgression of the Leszno-Pomeranian Phase of the Vistulian Glaciation; below sediments of the Gardno Phase ice-dammed lake (Czerniawska, 2004; Jasiewicz et al., 2005); below sediments of the Łupawa River, and under the Poddąbie Till. The till top occurs at a depth of $4.0 \mathrm{~m}$ a.s.I. up to $16 \mathrm{~m}$ b.s.I. The K/W petrographic coefficient value of, ranging from 0.89 to 1.26 , allows correlating the till with the Warta Glaciation.

Poddąbie Till was found in cliff exposures in Dębina and in older (Warta Glaciation) ice-dammed lake sediments (Jasiewicz et al., 2005) in the Łupawa River valley. It occurs as a basal till as well as a flow till deposited within the ice-dammed lake, derived from mudflats from the lake embankment and upland edges. The basal till, occurring as the substrate of ice-dammed lake sediments, was found at a depth of $12 \mathrm{~m}$ a.s.I up to $11 \mathrm{~m}$ b.s.I. In cliff exposures, the Poddąbie Till is glaciotectonically piled up. The K/W petrographic coefficient values, ranging from 0.55 to 0.85 , correlate with the basal till identified with the Leszczo-Pomeranian Phase of Vistulian Glaciation (Krzyszkowski et al., 1998).

The upper and lower members of the Dębina Till were recognized only in cliff exposures in Dębina and Poddąbie. The lower member is a flow till deposited in aquatic conditions Gravel fractions are characterized by a high content of chalk, up to $30 \%$ of the total sample. The upper member is a melt-out till. Its petrographic composition of gravel fractions is characterized by a balance between crystalline rocks and carbonates, originating from the Baltic basin. Both till levels are correlated with deglaciation stages of the Pomeranian Phase ice sheet (Jasiewicz, 2005).

The Gardno till is visible in a cross-section through the Gardno end moraine and discordantly covers a glacial deformation zone. In the cliff exposure, the till reaches a thickness of several tens of $\mathrm{cm}$ up to $2 \mathrm{~m}$. Despite the complete absence of carbonates, its petrographic distinctness in the $5-10 \mathrm{~mm}$ fraction is underlined by the very high content of alkaline granites (Jasiewicz et al., 2005).

\section{MATERIAL AND METHODS}

The study of the cliff included geological mapping of the existing and self-made exposures. Three investigated profiles were analysed in detail (Fig. 3). Each mapped sediment layer was thoroughly described, including data on transport directions recorded in ripple marks, and on the direction and dip of clay and mud layers. Measurements of the orientation of long axes of clasts in the till were made using a geological compass. The final effect of the geological mapping is a classification of the individual layers of deposits by using a lithofacies coding system (Krzyszkowski, 1993, 1996; Miall, 1996; Dobracki and Krzyszkowski, 1997; Zieliński and Pisarska-Jamroży, 2012). The lithology is presented in a mode proposed by Rutkowski (1995), including the maximum grain size.

A number of lithologic types, which were identified in the exposures, were defined, and a total number of 19 samples were collected from the most typical layers. Results obtained from weathered till, flow-till or non-in-situ till have been rejected. Petrographic analysis of the gravel fraction $5-10 \mathrm{~mm}$ was performed in order to determine petrographic coefficients which are the basic tool for the distinction of lithostratigraphic units on the DGMP 1:50,000. The results obtained from tills, which were determined to be weathered, flow or not present in situ, were rejected as not accurate for the correct calculation of average $\mathrm{O} / \mathrm{K}-\mathrm{W} / \mathrm{A} / \mathrm{B}$ petrographic coefficients and the determination of local lithotypes of glacial tills (Lisicki, 2000). The deposits were then subjected to grain-size analysis using a set of sieves with mesh diameters of $1.0,0.5,0.25,0.1$ and $0.05 \mathrm{~mm}$, and to aerometric analysis. The results of both analyses were combined using a method provided by Mycielska-Dowgiałło (1995). The materials include also the results of measurements of transport directions in the ripple-mark structures, the direction and angle of dip of beds, radiocarbon dates as well as palynological and mollusc analysis.

\section{RESULTS}

\section{RESEARCH SITES NEAR PODDABIE}

In the Poddabie area, there are six individual lithostratigraphic units. The lowermost layer is represented by sands and clays of a glaciofluvial delta, which are overlain by the Poddąie Till, glaciolacustrine deposits of the Wytowno Formation, and lacustrine deposits of the Orzechowo Formation with a thick peat layer, and aeolian series at the cliff crest.

Lower glaciodeltaic series and lower till. The glaciodeltaic deposits are found only in a local anticlinal zone to $226 \mathrm{~km}$ (Fig. 1). The exposed part of the deposits, approximately $5-6 \mathrm{~m}$ thick, is composed of fine sands, small-scale cross-laminated sandy clays, and two laminated diamictons with a thickness of up to $2 \mathrm{~m}$.

Poddąbie Till. The Poddąbie Till, 5-13 m thick, is found in the lower part of the cliff (Figs. 2 and 4), except in a small area at $\mathrm{km} 226$. The top of the till is well exposed and the deposits commonly pass into glaciolacustrine clays. The till is very massive, glacial disturbances (Dmm), dark grey to black in colour.

The Poddąie Till was examined at 15 survey points (Figs. 2 and 5). The overall distinct orientation of the till indicates glacial palaeotransport from the NNE or NE. However, the directions are different in some places, e.g. at points 7,8 and 13, which are located at the highest elevations, where the palaeotransport is from the NNW or NW. At point 5 , the measurement results are scattered.

Petrographic study of the deposits was done at 18 survey points. The till contains $82-94 \%$ of Scandinavian rocks and of Baltic provenance. In general, the dominant rock type is limestone, and the ratio of crystalline to carbonate rocks (K/W) varies from 0.32 to 0.88 (average 0.64 ), except for two samples (8 and 11 ), where the K/W is 1.1 (Table 1).

The content of dolomites and Scandinavian sandstones and quartzites $(0.0-5.2 \%)$ is relatively low, and Paleozoic shales are very rare $(0.02 \%)$. Moreover, it seems that the petrographic characteristics of gravels change towards the upper part of the till. Its lower part is the richest in limestones (K/W is $~ 0.6$ ) which are less abundant in the middle part ( $\mathrm{K} / \mathrm{W}$ is $\sim 0.81$ ). The uppermost part of the till contains a little bit more crystalline rocks than limestones ( $\mathrm{K} / \mathrm{W}$ is $\sim 1.1$ ).

The content of local rocks ranges from 8 to $18 \%$. The dominant elements are Mesozoic sandstones and milky quartz grains. Mudstones and phosphosiderite concretions are less frequent. Cretaceous limestones and marls are rare (Table 1).

Wytowno Formation. The Wytowno Formation consists of glaciolimnic deposits immediately overlying the Poddabie Till, ranging in thickness from 1 to $10 \mathrm{~m}$ along the section of 225.5-227 km (Fig. 6). They can be subdivided into three units: deltaic, lower diamicton, and upper diamicton (Figs. 5 and 7). 

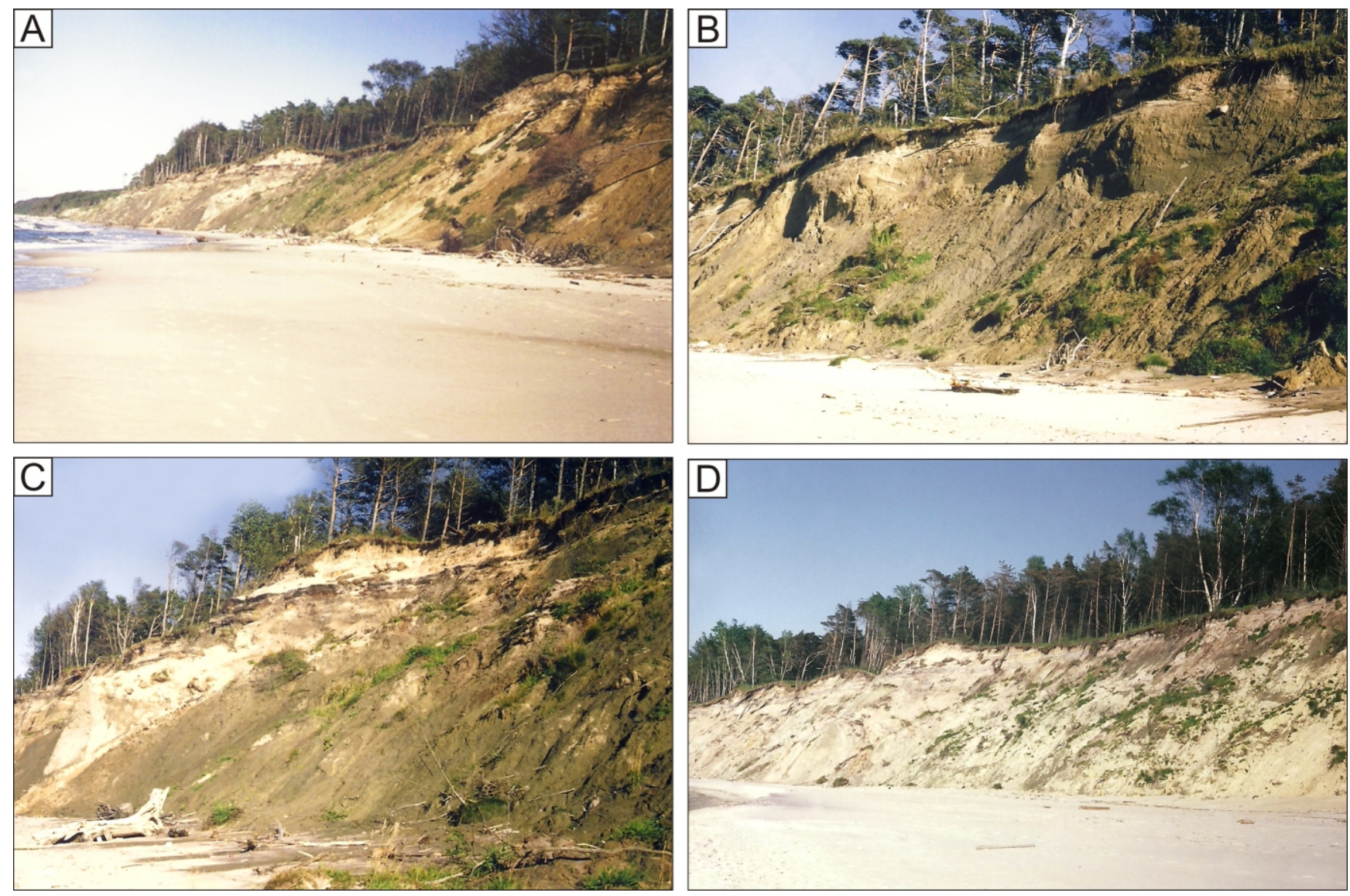

Fig. 4. The Poddąbie Till

A - view of the cliff from the NE; B - view of the left part of the cliff; C - view of the middle part of the cliff; $\mathbf{D}$ - view of the right part of the cliff

The deltaic lithofacies occur in the SW part of the cliff $(8$, 3-5; Fig. 6). These are largely fine-grained sands or sandy muds with current ripple-marks, or, rarely, laminated sands, muds, varved clays and highly compressed muds. Most probably, they represent the basement of the lower part of a gently inclined slope of a proglacial lake basin.

The base of the lithofacies is represented by three different till types. These are finely laminated clays and highly compressed clays with dropstones. All these sediments were deposited in the distal part of the lake and are present only at some sites (12, 4A and 1B; Fig. 6). The other lower lithofacies types are more common and represent deposits of relatively shallow lake.

Diamictons have been found within the deltaic and basal lithofacies. They form beds ranging in thickness from several millimetres to $0.5 \mathrm{~m}$, are laterally discontinuous, and extend over distances of 50-100 m. Two diamicton types are identified: sandy (resembling the till from Poddąbie) and clayey. Sandy diamictons commonly occur in the upper part of limnoglacial deposits and show a similar lithological and petrographic composition to the Poddąbie Till (Table 1). Sample 16 comes from decalcified till and is enriched in resistant minerals. Clayey diamictons contain few clasts, but their gravel content is similar to that of the Poddabie Till, except for one diamicton that is enriched in lake marl (survey point 7). The orientation of clasts is variable, usually scattered, but there are two sites where the material is clearly oriented (Figs. 3 and 6).
Orzechowo Formation. The Orzechowo Formation deposits are mostly discordantly overlain by a peat layer (Figs. 2 and 8). At two sites (9B and 6) there is another unit between them, 30-50 cm in thickness, represented by limnic mud containing a mollusc fauna. The full sequence of the Orzechowo Formation consists of organic mud (point 6) or peat (9B), light grey or light brown clay, dark brown to grey clay, and upper peat (Figs. 8 and 9). The upper peat layer is up to $30 \mathrm{~cm}$ thick (Fig. 9B), and at the other sites its thickness varies from several to $60 \mathrm{~cm}$. In its uppermost part the peat is usually interbedded with medium- and coarse-grained sand.

The thin peat layer $(1-5 \mathrm{~cm})$ is dated at $12,030 \pm 260{ }^{14} \mathrm{C}$ years ( $\mathrm{Gd} 10835$ ), overlain by an $\sim 30-\mathrm{cm}$ peat layer dated in the lower part at 10,240 \pm 110 ( Gd 11428) and in the upper part at 10,832 \pm 220 (Gd 10510; Figs. 8 and 9B; Table 2).

The lower part of the lacustrine sequences contains relatively abundant mollusc remains (Table 3 ) and pollen (Fig. 10).

Fluvio-aeolian and aeolian units. The peat is directly overlain by a number of 1-3 m-thick sand-muddy series containing medium- and coarse-grained laminated sands, clays and highly compressed sands.

The uppermost series of the cliff at Poddąbie is represented by aeolian deposits of well-developed dunes (Figs. 2 and 11). Two separate palaeosols dated at 2,100 \pm 210 ( $\mathrm{Gd} \mathrm{10745)}$ and $1,670 \pm 110$ ( $G d 10746)$ show that there were two major stages of aeolian activity in this area during the late Holocene (Table 2). The dunes are composed of horizontally and 

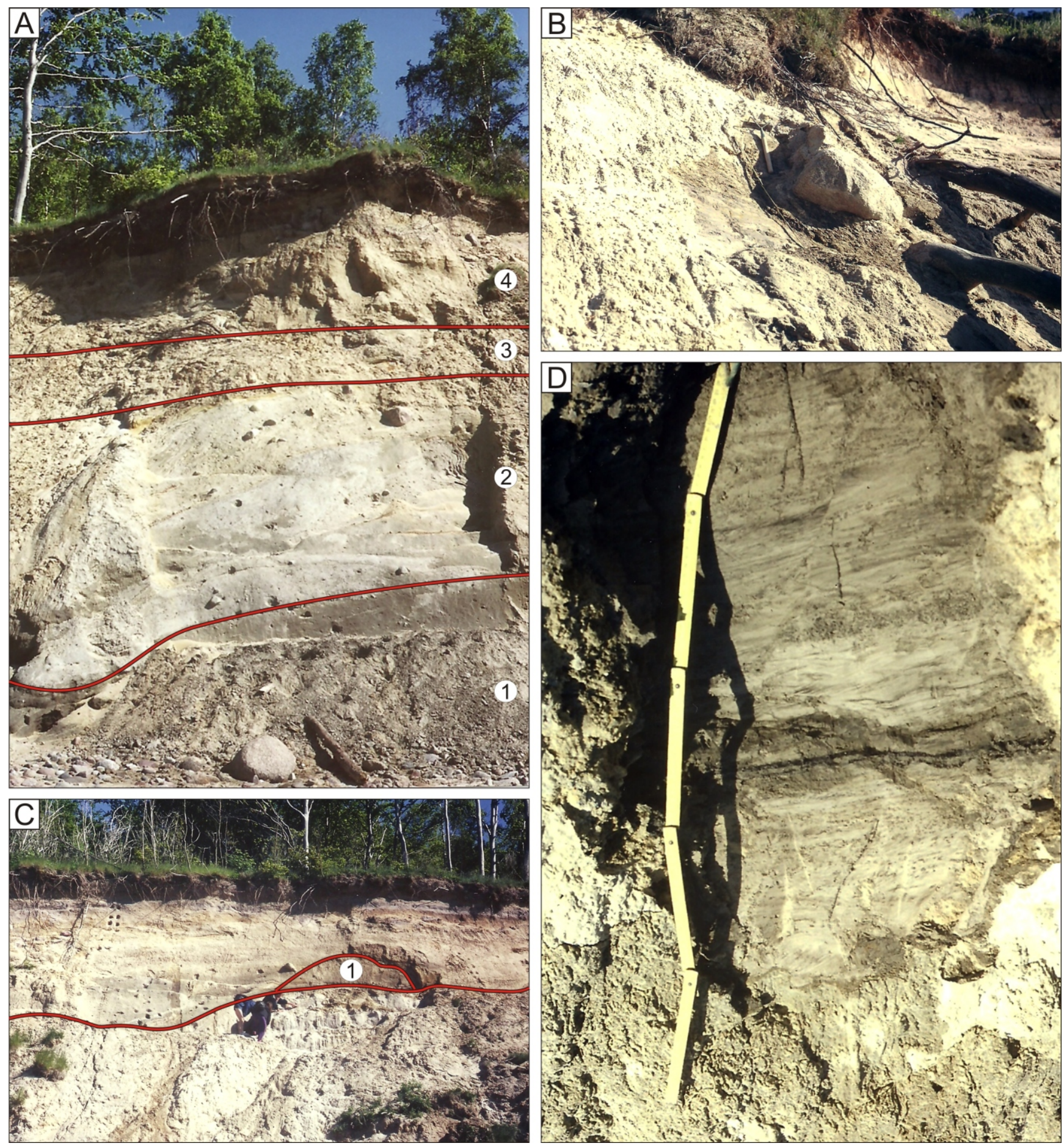

Fig. 5. The Poddąbie cliff deposits

A - 1 - till, 2 - varved clay, 3 - fluvio-aeolian, 4 - aeolian; B - boulders in diamicton/varved clay; C - 1 - silt and peat; D - varved clay 
Percentage petrographic composition of tills at Poddąbie in the fraction 5-10 mm

\begin{tabular}{|c|c|c|c|c|c|c|c|c|c|c|c|c|c|c|c|c|c|c|c|c|c|}
\hline \multirow[b]{2}{*}{ 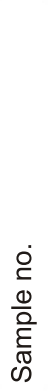 } & \multirow[b]{2}{*}{ 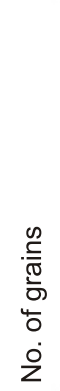 } & \multicolumn{4}{|c|}{ NORTHERN } & \multicolumn{2}{|c|}{ ROCKS } & \multicolumn{10}{|c|}{ LOCAL ROCKS } & \multicolumn{4}{|c|}{$\begin{array}{l}\text { PETROGRAPHIC } \\
\text { COEFFICIENTS }\end{array}$} \\
\hline & & 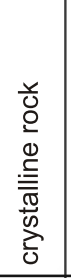 & $\begin{array}{l}\frac{N}{\pi} \\
\frac{0}{\sigma}\end{array}$ & 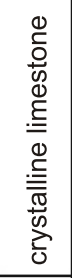 & $\begin{array}{l}\stackrel{0}{\stackrel{ \pm}{\varepsilon}} \\
\frac{0}{0} \\
\text { 응 }\end{array}$ & 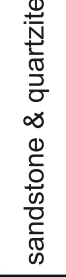 & 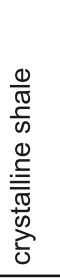 & 垔 & 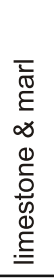 & $\begin{array}{l}0 \\
\stackrel{0}{0} \\
\frac{0}{0} \\
\frac{0}{0} \\
\frac{\mathbb{D}}{0}\end{array}$ & $\begin{array}{l}0 \\
\stackrel{0}{0} \\
\frac{0}{00} \\
\frac{0}{0} \\
\text { E }\end{array}$ & 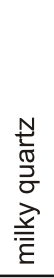 & $\stackrel{\vec{E}}{\stackrel{\underline{E}}{E}}$ & 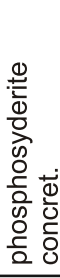 & 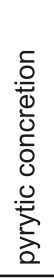 & 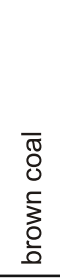 & $\begin{array}{l}\text { 으 } \\
\text { 임 } \\
\bar{\Phi} \\
\stackrel{ \pm}{0}\end{array}$ & $\mathrm{O} / \mathrm{K}$ & $\mathrm{K} / \mathrm{W}$ & $\mathrm{A} / \mathrm{B}$ & $\mathrm{Dp} / \mathrm{Wp}$ \\
\hline 2 & 396 & 21.2 & 5.8 & 61.1 & 0 & 2 & 0 & 8.7 & 0 & 4.8 & 0 & 2.2 & 1 & 0.2 & 0 & 0.5 & 1 & 2.65 & 0.43 & 2.1 & 0.01 \\
\hline 3 & 202 & 29.7 & 4.4 & 53.4 & 0.5 & 2.4 & 0 & 9.3 & 0.5 & 2.5 & 0 & 2.4 & 0.5 & 0.5 & 0.5 & 0 & 2.4 & 1.78 & 0.63 & 1.47 & 0.01 \\
\hline 1 & 421 & 23 & 2.3 & 59.8 & 1.6 & 2.3 & 0 & 10.5 & 0 & 6.1 & 1.4 & 2.3 & 0 & 0.5 & 0.2 & 0 & 0 & 2.75 & 0.41 & 2.2 & 0.02 \\
\hline 19 & 427 & 32.3 & 0.9 & 53.9 & 1.6 & 2 & 0 & 9.3 & 0 & 7 & 1.4 & 0.9 & 0 & 0 & 0 & 0 & 0 & 1.73 & 0.6 & 1.58 & 0.03 \\
\hline 20 & 266 & 39.5 & 1.1 & 47 & 2.2 & 0.8 & 0.4 & 9 & 0 & 4.9 & 2.2 & 1.5 & 0 & 0.4 & 0 & 0 & 0 & 1.24 & 0.82 & 1.2 & 0.05 \\
\hline 4 & 170 & 38.2 & 2.9 & 42.3 & 1.2 & 4.1 & 0 & 11 & 0 & 2.9 & 1.1 & 2.9 & 0 & 0.6 & 0 & 3.5 & 0 & 1.2 & 0.87 & 0.96 & 0.02 \\
\hline 5 & 229 & 27.9 & 5.2 & 46.7 & 0.8 & 5.2 & 0.8 & 12.9 & 0.4 & 2.2 & 0.4 & 2.6 & 0.8 & 3.5 & 0 & 3 & 0 & 1.68 & 0.65 & 1.26 & \begin{tabular}{|l|l}
0.01 \\
\end{tabular} \\
\hline 6 & 170 & 26.4 & 2.3 & 57 & 0.5 & 5.3 & 0 & 8.1 & 0 & 5.9 & 0 & 0 & 1.1 & 0 & 0 & 0 & 1.1 & 2.28 & 0.5 & 1.69 & \begin{tabular}{|l|l}
0.01 \\
\end{tabular} \\
\hline 7 & 237 & 18.9 & 2.5 & 62.4 & 2.5 & 5.5 & 0 & 8 & 0 & 5.5 & 0 & 0 & 0 & 0.4 & 0 & 1.7 & 0.4 & 3.39 & 0.32 & 2.4 & 0.04 \\
\hline 13 & 334 & 39.5 & 4.1 & 45.8 & 0.9 & 2 & 0.3 & 7.2 & 0 & 3.9 & 0 & 0 & 0 & 0.6 & 0 & 2.7 & 0 & 1.26 & 0.88 & 1.03 & 0.01 \\
\hline 14 & 155 & 32.6 & 2.5 & 39.1 & 2.5 & 3.8 & 0 & 18.3 & 0 & 5.7 & 0 & 2.5 & 1.3 & 2.5 & 0.6 & 5.7 & 0 & 1.41 & 0.74 & 1.06 & 0.06 \\
\hline 8 & 321 & 47 & 2.4 & 44.5 & 0.3 & 2.2 & 0 & 3.3 & 0 & 1.8 & 0 & 1.5 & 0 & 0 & 0 & 0 & 0 & 0.99 & 1.1 & 0.86 & 0.01 \\
\hline 11 & 174 & 45.9 & 3.4 & 42.5 & 1.7 & 0 & 0 & 6.2 & 0.5 & 2.8 & 0.6 & 0 & 0 & 2.3 & 0 & 0 & 0 & 1.02 & 1.11 & 0.9 & 0.04 \\
\hline 9 & 243 & 33.7 & 3.7 & 52.6 & 1.6 & 1.2 & 0 & 6.9 & 0 & 5.3 & 0 & 0 & 0 & 0.8 & 0 & 0.8 & 0 & 1.69 & 0.67 & 1.4 & 0.03 \\
\hline 10 & 605 & 26.2 & 3.8 & 52 & 0.6 & 5.7 & 0.2 & 11.1 & 0 & 3.6 & 0.5 & 2.4 & 0 & 1.5 & 0 & 3.1 & 0 & 2 & 0.79 & 1.47 & 0.01 \\
\hline 12 & 233 & 29.6 & 3 & 57.5 & 0 & 2.5 & 0 & 7 & 0 & 2.5 & 0.4 & 2.5 & 0 & 0.4 & 0 & 0.4 & 0 & 1.93 & 0.56 & 1.63 & 0 \\
\hline 15 & 178 & 21.9 & 6.7 & 52.8 & 0 & 5.6 & 0 & 12.8 & 0 & 7.8 & 0 & 0 & 0.5 & 0 & 0 & 4.5 & 0 & 2.35 & 0.5 & 1.54 & 0 \\
\hline 16 & 268 & 58.2 & 1.2 & 29.9 & 1.2 & 2.2 & 0 & 7.3 & 0 & 5.8 & 0 & 1.5 & 0 & 0 & 0 & 0 & 0 & 0.56 & 1.9 & 0.5 & 0.04 \\
\hline
\end{tabular}




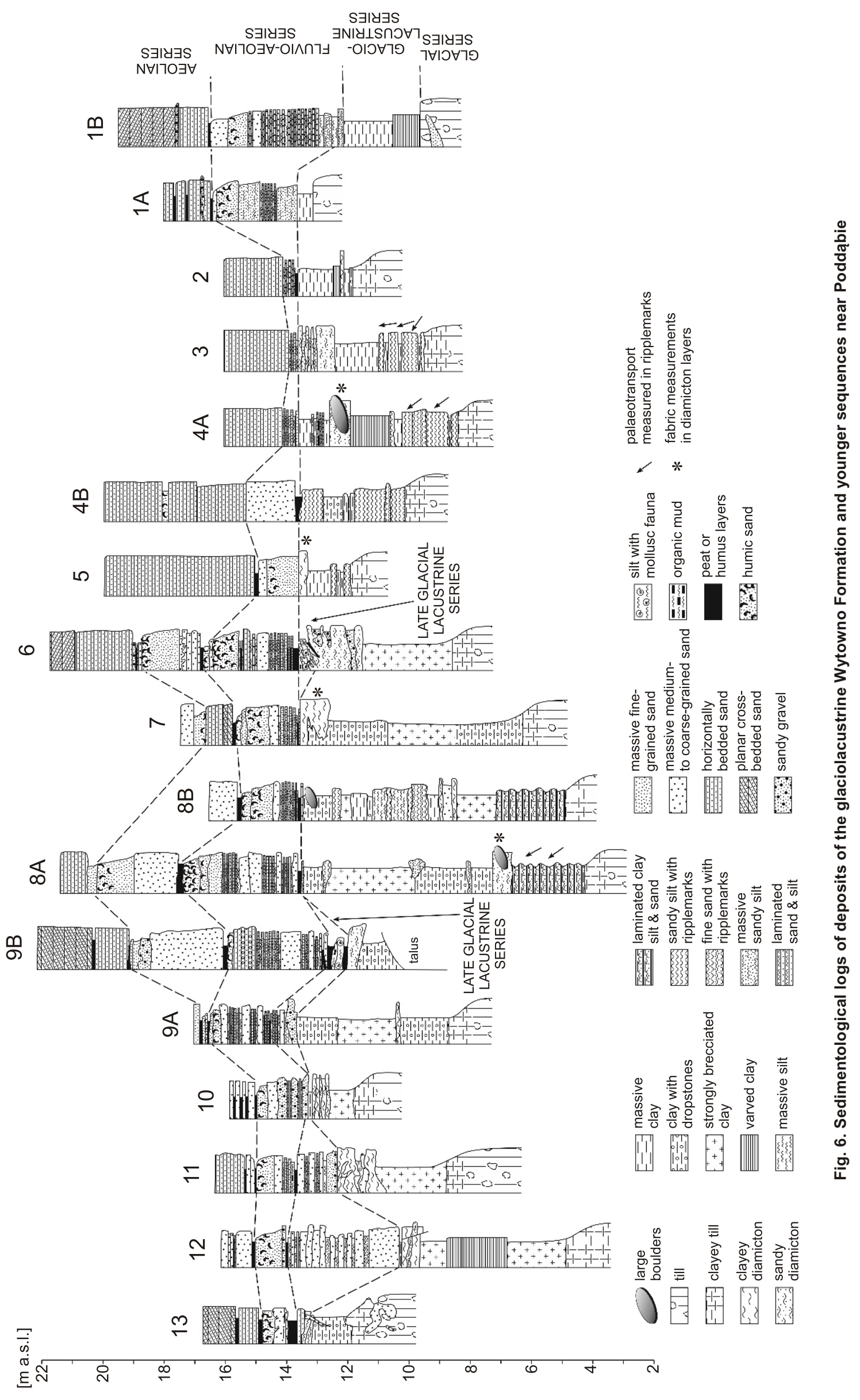



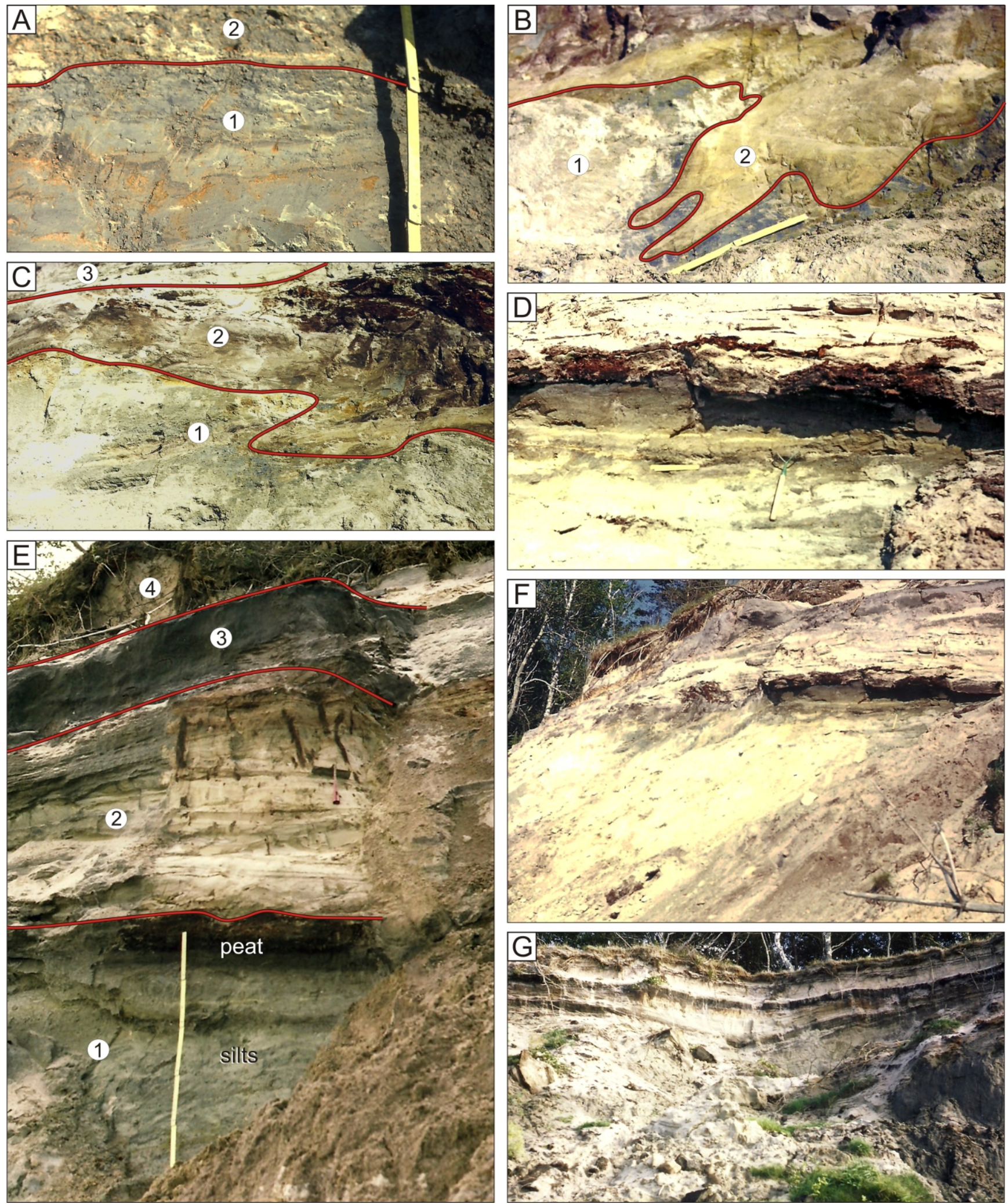

Fig. 7. The Wytowno Formation deposits

A - 1 - varved clay, 2 - silt with mollusc fauna; B - 1 - till/diamicton, 2 - laminated silt/peat mix; C - 1 - varved clay, 2 - organic mud, grey-green mud, fine sand, grey-green sand, dark brown mud, peat, 3 - fluvio-aeolian series; D - view of part of the cliff; $\mathbf{E}-1$ - peat/silt, 2 fluvio-aeolian unit, 3 - dark brown organic silt, 4 - aeolian unit; $\mathbf{F}$ - dark brown organic silt; $\mathbf{G}$ - fluvio-aeolian series and aeolian series 


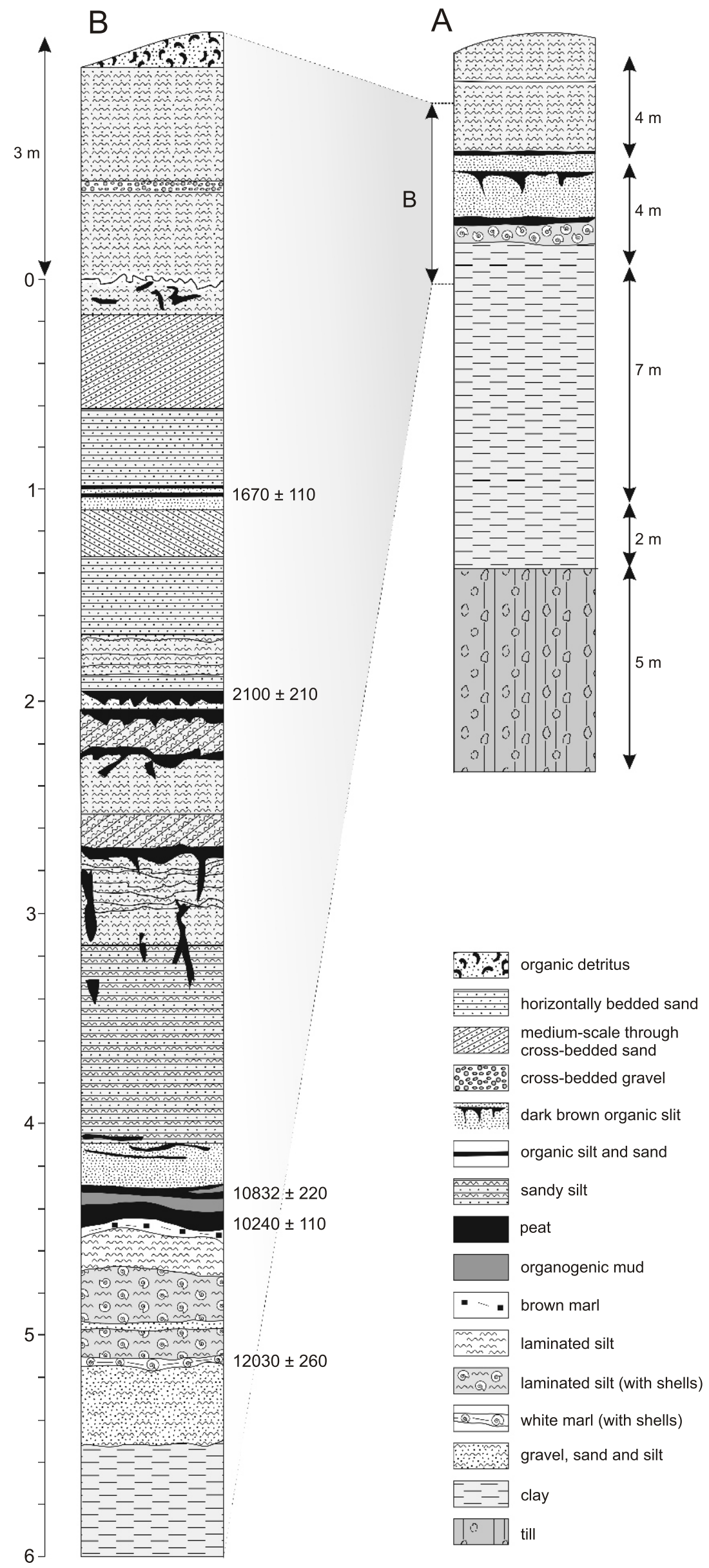

Fig. 8. Late Glacial lacustrine and fluvio-aeolian units 

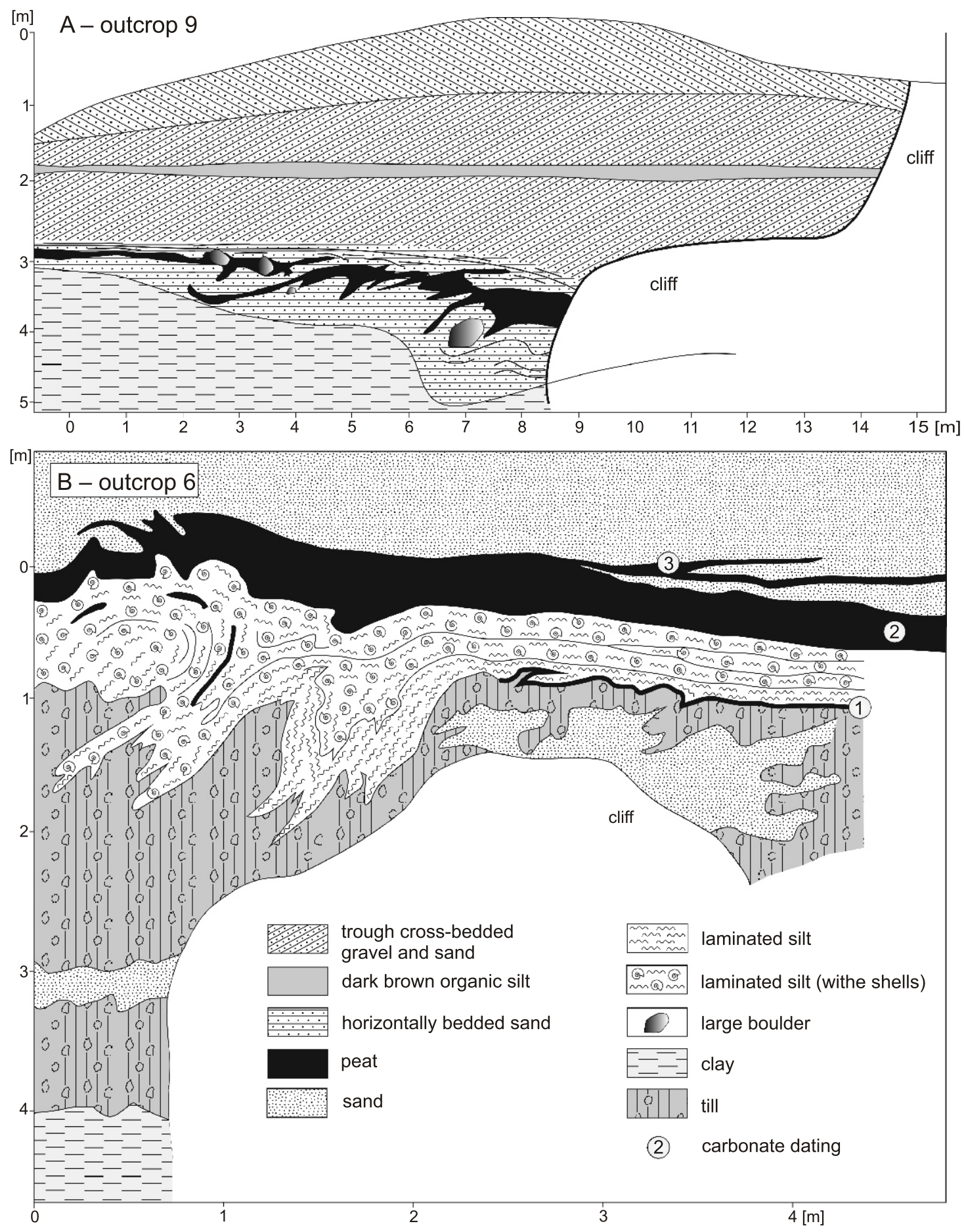

Fig. 9. Late Glacial lacustrine units 


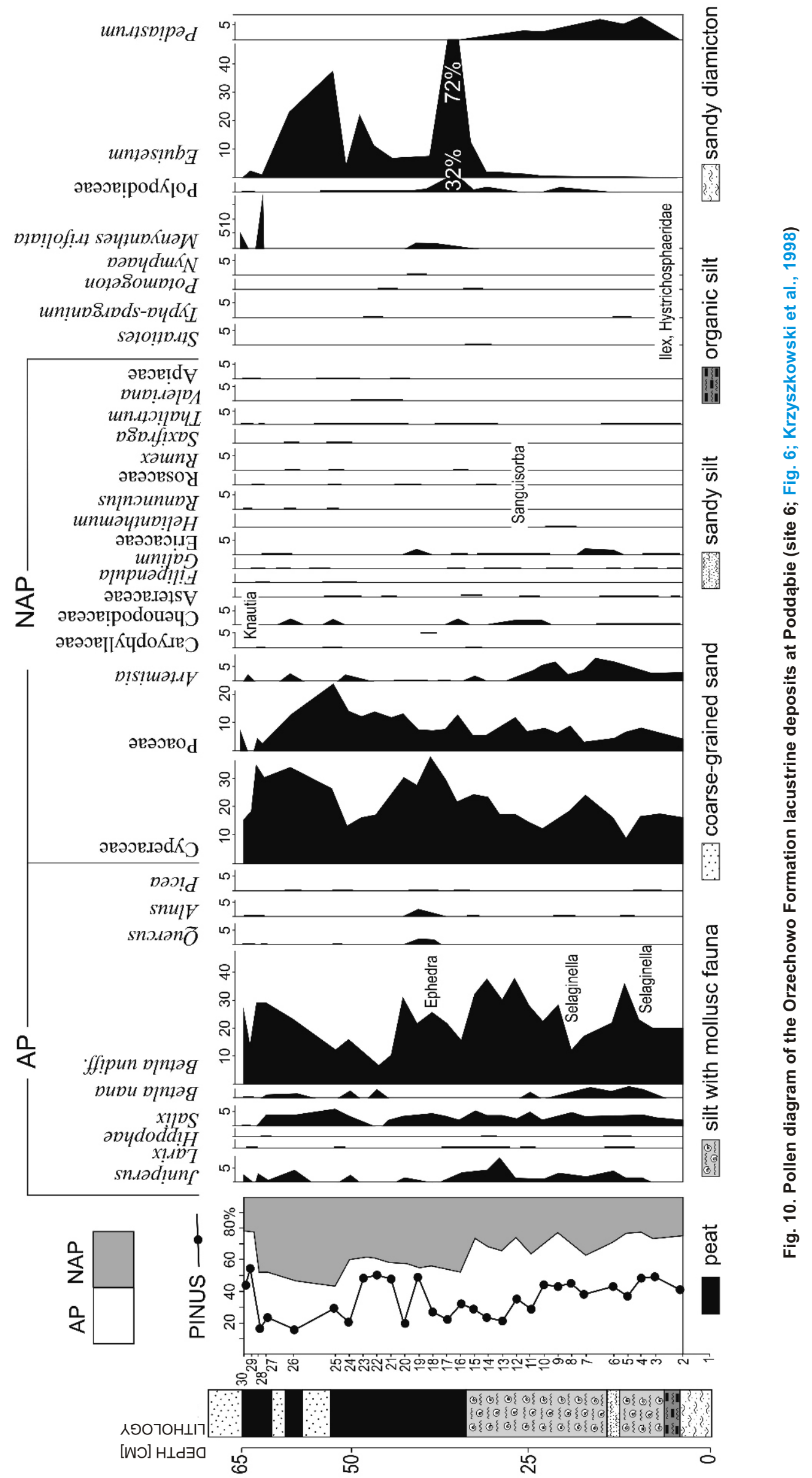




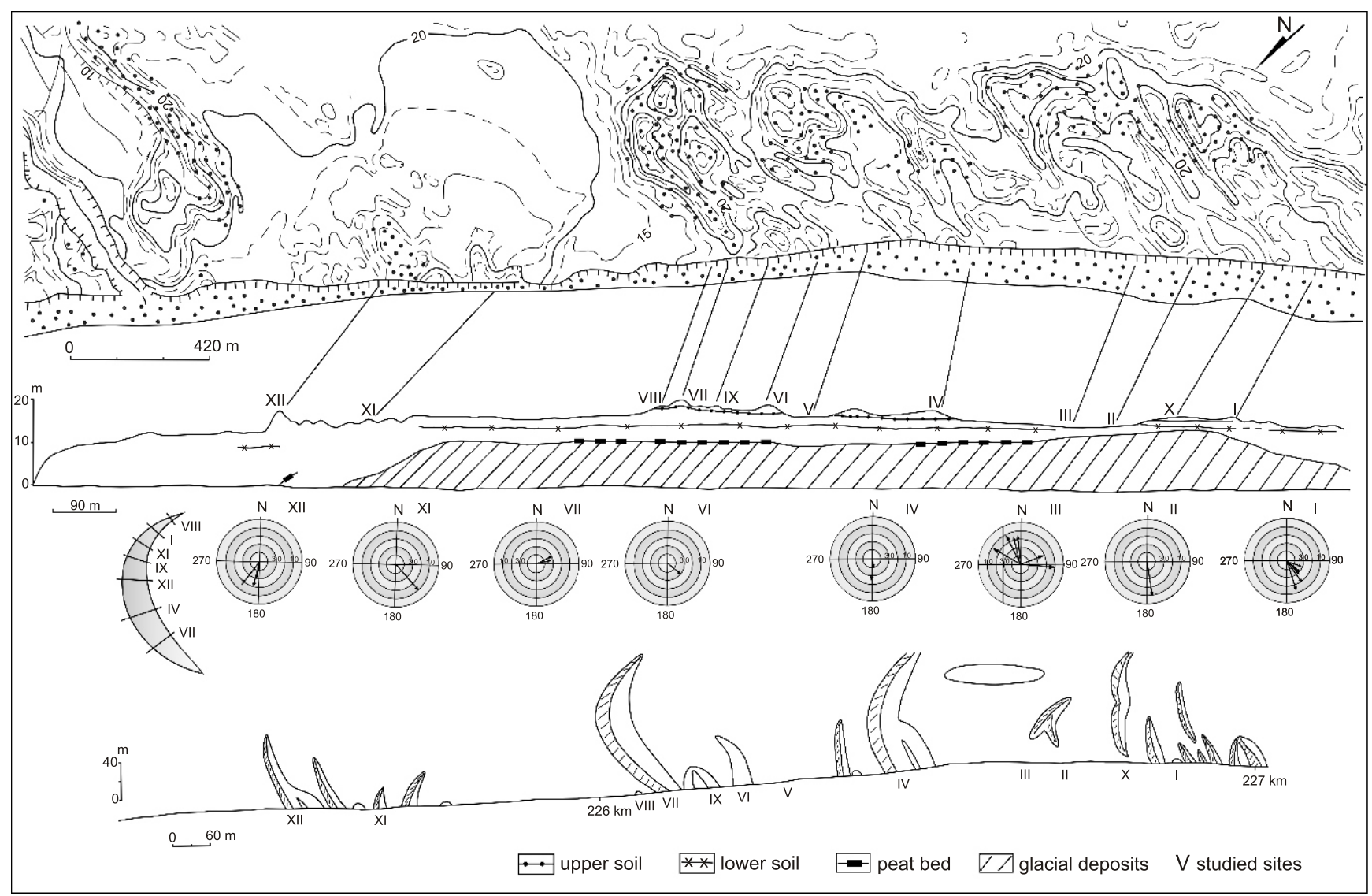

Fig. 11. Dunes near Poddąbie and possible palaeowind directions

Table 2

Mollusc fauna in lacustrine deposits at Poddąbie (Krzyszkowski et al., 1998)

\begin{tabular}{|c|c|c|c|c|c|}
\hline SPECIES & $\begin{array}{c}\text { lower organic } \\
\text { mud } \\
(1-3 \mathrm{~cm})\end{array}$ & $\begin{array}{l}\text { light brown } \\
\text { silt } \\
(3-8 \mathrm{~cm})\end{array}$ & $\begin{array}{l}\text { light brown } \\
\text { silt } \\
(8-15 \mathrm{~cm})\end{array}$ & $\begin{array}{l}\text { light brown } \\
\text { silt } \\
(15-22 \mathrm{~cm})\end{array}$ & $\begin{array}{l}\text { dark brown } \\
\text { silt } \\
(22-30 \mathrm{~cm})\end{array}$ \\
\hline Limacidae & & I & & & \\
\hline Lymnaea peregra & I & I & II & 1 & I \\
\hline Lymnaea occulta & I & I & I & I & I \\
\hline Armiger crist & & I & I & I & \\
\hline Gyraulus laevis & I & II & II & I & \\
\hline Sphaerium corneum & & 1 & 1 & III & III \\
\hline Pisidium nitidum & II & III & III & II & \\
\hline Pisidium milium & II & III & III & II & \\
\hline Pisidium subtruncatum & I & II & I & & \\
\hline Pisidium lillieborgi & & 1 & I & \multirow{2}{*}{\multicolumn{2}{|c|}{$\begin{array}{l}\text { Number of specimens: } \\
\text { I-1-3; II -4-9; III - 10-31 }\end{array}$}} \\
\hline $\begin{array}{l}\text { Pisidium obtusale } \\
\text { lapponicum }\end{array}$ & III & II & I & & \\
\hline
\end{tabular}


Table 3

Results of sediment dating at the Poddąbie site

\begin{tabular}{|c|c|c|}
\hline SAMPLES & SAMPLE CODE & YEARS BP \\
\hline Poddąbie 5 & Gd-10745 & $1,670 \pm 120$ \\
\hline Poddąbie 4 & Gd-10746 & $2,100 \pm 120$ \\
\hline Poddąbie 3 & Gd-10510 & $10,832 \pm 220$ \\
\hline Poddąbie 2 & Gd-11428 & $10,240 \pm 110$ \\
\hline \multirow[t]{3}{*}{ Poddąbie 1} & Gd-10835 & $12,030 \pm 260$ \\
\hline & GL-10959 & $\begin{array}{c}27,000 \pm 750 \\
\text { (Jasiewicz et al., 2005) }\end{array}$ \\
\hline & Gd-6844 & $\begin{array}{c}29,500 \pm 800 \\
\text { (Rotnicki, 2001) }\end{array}$ \\
\hline
\end{tabular}

cross-laminated medium-grained sands indicating palaeotransport from different directions (Figs. 9 and 11).

\section{PROFILES NEAR DEBINA}

Deposits of the Wytowno Formation and Dębina Till occur also in the cliff stretching between Poddabie and Dębina, and were analysed at three survey points along the section 222.5-223 km. Limnoglacial deposits, up to $40 \mathrm{~m}$ thick, are exposed in this area.

They are represented mainly by deltaic lithofacies including fine-grained sands, sandy clays with ripple marks of various types, and highly compressed flaser-laminated clays. They are sporadically found as dropstones that melted out from floating icebergs. These lithofacies probably represent a lake bottom environment

Profile I. The cliff crest consists of the present-day soil layer and the ancient soil layer, separated by a $2 \mathrm{~m}$ thick series of aeolian sands. Underneath the ancient soil, there is a $1 \mathrm{~m}$ thick layer of aeolian sands underlain by clayey till, $3 \mathrm{~m}$ in thickness.

The till reveals the upper brownish part that contains scarce pebbles (up to $10 \mathrm{~cm}$ across) and shows many discolourations due to iron compounds, as well as the basal grey part in which the quantity and size of pebbles decrease downwards. The till layer is underlain by fine-grained deposits (Dębina Till).

Fine-grained ripple-marked sands and silty sands alternate with massive or laminated sandy and clayey deposits or massive clays. Medium-grained sands with admixture of fine-grained sands are observed more rarely (Table 4). The characteristic features of this part of the cliff are numerous glaciotectonic deformation structures. Both low-amplitude faults, observed within a single bed or cutting a number of strata, and major faults, accompanied by fissures filled with clay and silty material, are common (Hart et al., 1990; Hart, 1991 Moretti, 2000).

Profile II. The deposits are dominated by fine-grained fractions. These include fine sands and silty sands, laminated, ripple-marked or massive, alternating with massive or laminated muds and massive clays. The characteristic feature, unknown from other sections, is a thin, merely $2 \mathrm{~cm}$ thick layer of varved clays. Individual laminae, light to dark grey, have a thickness of 1-2 $\mathrm{mm}$ and are highly coherent.

Profile III. At the cliff crest, there are two soil horizons of modern and ancient soil, separated by a $\sim 40 \mathrm{~cm}$ thick layer of dune sands. The ancient soil horizon is underlain by a $5 \mathrm{~cm}$ thick layer of coarse-grained sand which, in turn, is underlain by a sandy till layer, $2.3 \mathrm{~m}$ in thickness. The till (Dębina Till) is yellow at the top to beige and grey at the base, and shows discolouration due to the presence of iron compounds. It contains considerable amounts of gravel-sized fractions and numerous clasts, up to $20 \mathrm{~cm}$ in size. The till layer is underlain by fine sands and silty sands, which are laminated, ripple-marked and massive. They occur alternately with massive or laminated muds and massive clays. There are also sporadic medium-grained sands with admixture of fine grains.

From profiles I, II and III, samples were collected for the studies summarized in Table 4.

The Dębina Till of profile I was investigated for the orientation of long axes of clasts. The measurements were made separately for two identified parts of the till: (1) the grey basal part, and (2) the brown upper part. The results are presented on pie charts (Figs. 12 and 13). For the upper part of the till, the resultant main transport is NE-SW. In the basal part of the till, a bimodal pattern is observed. The main transport direction is NE-SW, and the minor direction is NW-SE (Figs. 12 and 13).

The measurements of ripplemark structures were performed on sandy and sand-muddy deposits of profiles I and III. The results are summarized in Figures 12 and 13. Based on the analyses carried out at the three sites, the following characteristic types of deposits have been identified in the examined part of the cliff (see: Figs. 12 and 13):

Type I: represented by sediment D/118, transported by traction, medium sand with admixture of fine sand, poorly sorted, consists of massive (Sm), ripple-marked (Sr) and flaser (Sf) deposits.

Type II: represented by ripple-marked sands (Sr): D/105 and $\mathrm{D} / 108$, fine sands, transported in homogeneous suspension, poorly sorted. It also includes massive and flaser deposits (Sf, Sm).

Type III: represented by: Illa - laminated deposits (SFh, FSh, SFw, FSw) D/104 - sandy mud; IIlb - ripple-marked deposits (SFr, FSr) D/109 - very fine silty sand; IIIC - flaser deposits $\mathrm{D} / 110$ - sandy silt, and massive deposits (SFm, FSm), silty sands or sandy muds, transported in suspension, poorly or very poorly sorted.

Type IV: represented by D/107, D/115 and IVb - laminated muds (Fh), and by D/106 - muds, transported in homogeneous suspension or deposited from pelagic suspension.

Type V: represented by massive deposits $(F m) D / 112$ and $\mathrm{D} / 114$, silty clays, deposited from pelagic suspension, very poorly sorted.

Type VI: represented by massive deposits (Fm) - D/119, deposited from pelagic suspension, the sediment is almost equigranular, its poor sorting may be the effect of a small depth of the sedimentary basin.

Type VII: represented by varved clays - D/116 (Fv), grain-size features as in massive clays. Small thickness of laminae (Table 4) may suggest that environmental conditions, which favoured deposition of varved clays, lasted very short and the supply of material was low at that time (profile II).

Type VIII: represented by D/111, silty sand showing strongly deformed ripple-marked structure (FSd), fine-grained deposits, deposited from heterogeneous suspension, very poorly sorted.

Type IX: represented by glacial tills (Dębina Till) deposited directly from the ice sheet, very poorly sorted; two till types are distinguished:

- heavy clayey till (Dmm), represented by D/101, D/102 and D/103 (profile I, Table 4);

- sandy till (Dmm), represented by D/117 (profile III, Table 4). 
Lithological characteristics of the deposits

\begin{tabular}{|c|c|c|c|c|}
\hline $\begin{array}{l}\text { Sample no. } \\
\text { Site } \\
\text { (position of layer } \\
\text { in the section - } \\
\text { depth interval) }\end{array}$ & $\begin{array}{l}\text { Deposit description } \\
\text { [thickness] }\end{array}$ & 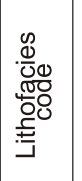 & 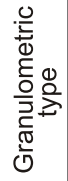 & Sedimentary conditions \\
\hline $\begin{array}{l}\mathrm{D} / 101 / / \mathrm{A} \\
(4.00-5.60 \mathrm{~m})\end{array}$ & $\begin{array}{l}\text { Brown till, scarce clasts } \phi \text { up to } 10 \mathrm{~cm} ; \text { Fe discolouration; } \\
\text { grades into grey till }(D / 101-102) ;[160-170 \mathrm{~cm}]\end{array}$ & $\mathrm{Dmm}$ & IX & Glacial till, effects of successive glaciations \\
\hline $\begin{array}{l}\mathrm{D} / 102 / \mathrm{IA} \\
(5.60-7.10 \mathrm{~m})\end{array}$ & $\begin{array}{l}\text { Grey till (sample from top part), scarce pebbles } \phi<5 \mathrm{~cm} \text {; } \\
\text { Fe discolouration at the top; }[150-180 \mathrm{~cm}]\end{array}$ & Dmm & IX & Glacial till, effects of successive glaciations \\
\hline $\begin{array}{l}\mathrm{D} / 103 / \mathrm{IA} \\
(5.60-7.10 \mathrm{~m})\end{array}$ & $\begin{array}{l}\text { Grey till (sample from basal part), sporadic pebbles } \phi<3 \mathrm{~cm} \text {; } \\
\text { no Fe discolouration }\end{array}$ & Dmm & IX & Glacial till, effects of successive glaciations \\
\hline $\begin{array}{c}\mathrm{D} / 104 / \mathrm{IA} \\
(8.60-8.70 \mathrm{~m})\end{array}$ & $\begin{array}{l}\text { Laminated sandy silt, Fe discolouration; dark and light grey } \\
\text { laminae }(0.5-1.0 \mathrm{~cm}) \text {; strongly deformed layer, cut by faults } \\
\text { and bent; }[3-14 \mathrm{~cm}]\end{array}$ & SFh & IIla & Deposition from turbidity currents \\
\hline $\begin{array}{l}\mathrm{D} / 105 / 1 \mathrm{~A} \\
(9.10-9.95 \mathrm{~m})\end{array}$ & $\begin{array}{l}\text { Silty sand, grey-beige, ripple-marked bedded (152), with black } \\
\text { streaks (heavy minerals) and Fe discolouration; [ } 80-90 \mathrm{~cm}]\end{array}$ & $\mathrm{Sr}$ & II & $\begin{array}{l}\text { Layer } \mathrm{C} \text { of turbidite sequence, joint action of } \\
\text { traction and rapid settling of grains from } \\
\text { suspension }\end{array}$ \\
\hline $\begin{array}{c}\mathrm{D} / 106 / \mathrm{AA} \\
(9.95-10.13 \mathrm{~m})\end{array}$ & $\begin{array}{l}\text { Laminated sandy silt, Fe discolouration at the base; layer cut by } \\
\text { faults; flat prallel laminae } 0.5-2.5 \mathrm{~cm} \text { thick, light and dark beige } \\
\text { and light and dark grey; }[18 \mathrm{~cm}]\end{array}$ & $\mathrm{Fh}$ & $\mathrm{IVb}$ & $\begin{array}{l}\text { Layer B of Bouma turbidite sequence, } \\
\text { upper flow regime }\end{array}$ \\
\hline $\begin{array}{c}\mathrm{D} / 107 / \mathrm{IE} \\
(39.20-39.70 \mathrm{~m})\end{array}$ & $\begin{array}{l}\text { Massive mud, pale grey, Fe discolouration at the top; at the } \\
\text { base (at the contact with layer D/108), single angular clasts } \\
\phi \text { up to } 9 \mathrm{~cm} ;[45-50 \mathrm{~cm}]\end{array}$ & $\mathrm{Fm}$ & IVa & $\begin{array}{l}\text { Free deposition from pelagic suspension; } \\
\text { contact between basin and ice-dropstones; } \\
\text { middle part of the delta }\end{array}$ \\
\hline $\begin{array}{c}\mathrm{D} / 108 / \mathrm{IE} \\
(39.70-40.20 \mathrm{~m})\end{array}$ & $\begin{array}{l}\text { Very fine sand, light beige, ripple-marked bedded (deformed } \\
\text { bedding), Fe streaks (at the contact with layer D/107), single } \\
\text { angular clasts } \phi \text { up to } 9 \mathrm{~cm}[48-50 \mathrm{~cm}]\end{array}$ & $\mathrm{Sr}$ & II & $\begin{array}{l}\text { Bottom currents activity; contact between } \\
\text { basin and ice-dropstones; } \\
\text { middle part of the delta }\end{array}$ \\
\hline $\begin{array}{c}\mathrm{D} / 109 / \mathrm{IA} \\
(10.13-10.73 \mathrm{~m})\end{array}$ & $\begin{array}{l}\text { Muddy sand, light grey and light yellow, ripple-marked bedded } \\
\text { (157), with black streaks (heavy minerals) and Fe; [55-65 cm] }\end{array}$ & SFr & IIIb & $\begin{array}{l}\text { Joint action of bottom currents and rapid settling } \\
\text { of sand grains from suspension; middle part of } \\
\text { the delta }\end{array}$ \\
\hline $\begin{array}{c}\mathrm{D} / 110 / \mathrm{IA} \\
(11.25-11.85 \mathrm{~m})\end{array}$ & $\begin{array}{l}\text { Grey sandy silt, with lighter and darker streaks, numerous } \\
\text { deformation structures, faults; }[60 \mathrm{~cm}]\end{array}$ & SFd & IIIC & $\begin{array}{l}\text { Joint action of bottom currents and rapid settling } \\
\text { of sand grains from suspension; middle part of } \\
\text { the delta }\end{array}$ \\
\hline $\begin{array}{c}\mathrm{D} / 111 / \mathrm{IA} \\
(13.20-14.00 \mathrm{~m})\end{array}$ & $\begin{array}{l}\text { Fine sand, light beige, very thin interlayers of brown mud; } \\
\text { the whole is ripple-marked bedded, strongly deformed, cut by } \\
\text { faults; }[70-85 \mathrm{~cm}]\end{array}$ & FSd & VIII & $\begin{array}{l}\text { Activity of turbidity currents; middle part of the } \\
\text { delta; pulsatory sediment supply }\end{array}$ \\
\hline $\begin{array}{c}\mathrm{D} / 112 / \mathrm{IA} \\
(12.90-13.20 \mathrm{~m})\end{array}$ & Silty clay, massive, grey $(156 / 30) ;[30 \mathrm{~cm}]$ & $\mathrm{Fm}$ & V & $\begin{array}{l}\text { Free deposition from pelagic suspension; } \\
\text { middle part of the delta }\end{array}$ \\
\hline $\begin{array}{c}\mathrm{D} / 113 / \mathrm{II} \\
(18.70-20.90 \mathrm{~m})\end{array}$ & $\begin{array}{l}\text { Fine sand, ripple-marked bedded in the lower part, with black } \\
\text { streaks (heavy minerals), light grey; }[220-230 \mathrm{~cm}]\end{array}$ & SC & II & $\begin{array}{l}\text { Activity of turbidity currents; middle part of the } \\
\text { delta }\end{array}$ \\
\hline $\begin{array}{c}\mathrm{D} / 114 / \mathrm{II} \\
(21.30-21.40 \mathrm{~m})\end{array}$ & $\begin{array}{l}\text { Silty clay }(151 / 26) \text {, grey-brown, with a thin layer of }(0.5 \mathrm{~cm}) \\
\text { light grey fine sand; }[10-12 \mathrm{~cm}]\end{array}$ & $\mathrm{Fm}$ & V & $\begin{array}{l}\text { Free deposition from pelagic suspension; } \\
\text { distal part of the delta }\end{array}$ \\
\hline $\begin{array}{c}\mathrm{D} / 115 / \mathrm{II} \\
(25.50-25.78 \mathrm{~m})\end{array}$ & Grey mud with Fe discolouration; [26-28 cm] & $\mathrm{Fm}$ & IVa & $\begin{array}{l}\text { Free deposition from suspension; distal part of } \\
\text { the delta }\end{array}$ \\
\hline $\begin{array}{c}\mathrm{D} / 116 / \mathrm{II} \\
(26.18-26.20 \mathrm{~m})\end{array}$ & $\begin{array}{l}\text { Varved clay, compact and thin laminae }(0.1-0.2 \mathrm{~cm}) \text {, dark grey } \\
\text { and very light grey; }[2 \mathrm{~cm}]\end{array}$ & Fv & VII & $\begin{array}{l}\text { Free deposition from pelagic suspension; } \\
\text { distal part of the delta }\end{array}$ \\
\hline $\begin{array}{c}\mathrm{D} / 117 / \mathrm{III} \\
(1.50-3.80 \mathrm{~m})\end{array}$ & $\begin{array}{l}\text { Sandy till, yellow to grey at the base, very numerous clasts } \mathrm{f} \text { up } \\
\text { to } 20 \mathrm{~cm} \text {; Fe discolouration and green discolouration; }[230 \mathrm{~cm}]\end{array}$ & $\mathrm{Dm}$ & IX & Glacial till, glaciation period \\
\hline $\begin{array}{c}\mathrm{D} / 118 / \mathrm{III} \\
(6.20-7.25 \mathrm{~m})\end{array}$ & $\begin{array}{l}\text { Fine sand, massive, white-yellow, with a thin Fe-rimmed } \\
\text { interlayer of light grey sand (strongly deformed layer, with } \\
\text { faults); [100-110 cm] }\end{array}$ & $\mathrm{Sm}$ & I & $\begin{array}{l}\text { Melting season, activity of higher-energy } \\
\text { bottom currents }\end{array}$ \\
\hline $\begin{array}{c}\mathrm{D} / 119 / \mathrm{III} \\
(20.92-21.00 \mathrm{~m})\end{array}$ & Massive clay $(127 / 32)$, brown; [8 cm] & $\mathrm{Fm}$ & VI & $\begin{array}{l}\text { Free deposition from suspension; middle or } \\
\text { distal part of the delta }\end{array}$ \\
\hline
\end{tabular}



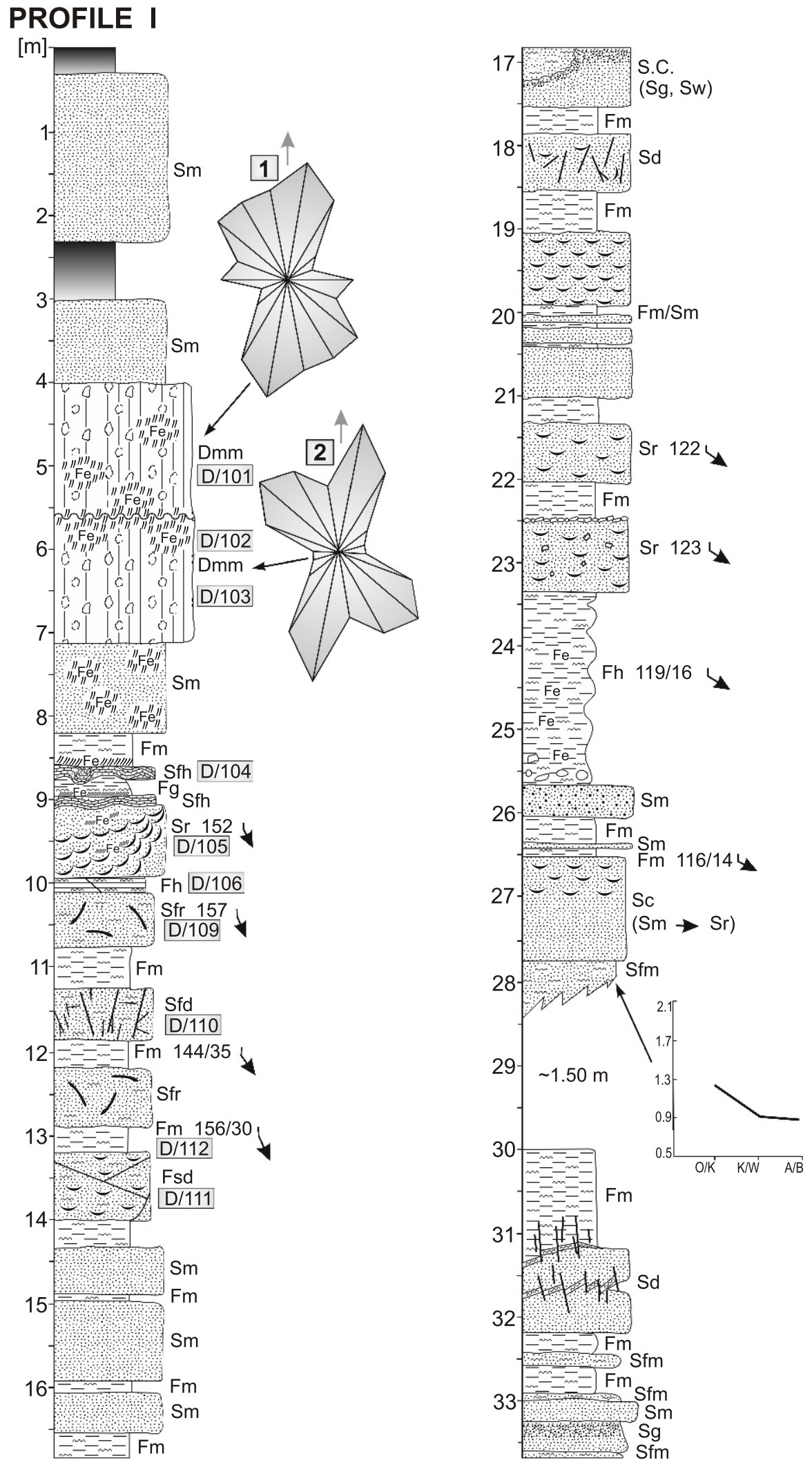

D/110 sampled sediment
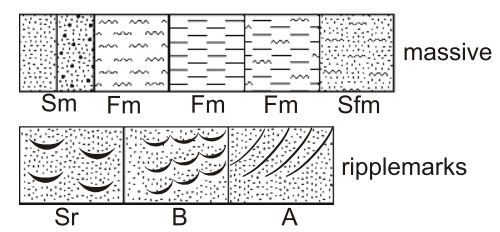

palaeotransport measured in ripplemarks

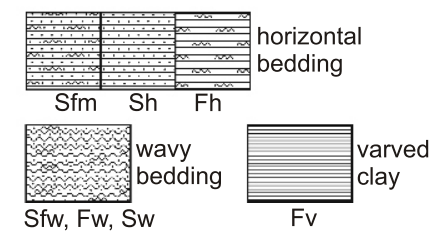

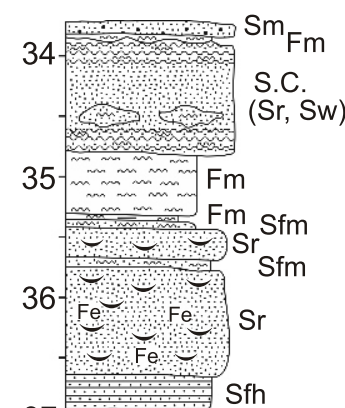

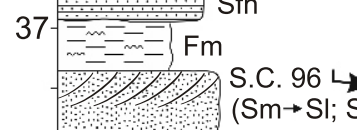

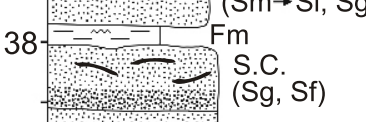

39

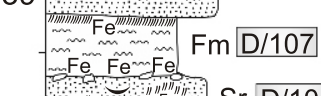

40-

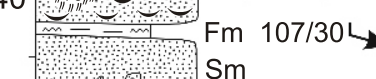

Anst. S Sm
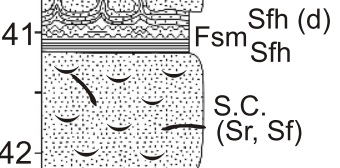

$\mathrm{Fe}-\mathrm{Sfh}$

- Fe Sfg 104/32 L

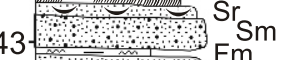
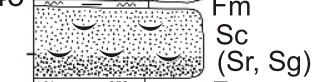

$44=$ Fm Sm

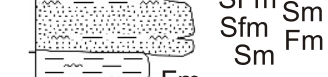

45

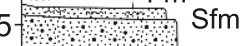

+. Sm

$46-$

$5.0-5.5 \mathrm{~m}$

${ } _ { 5 1 } \longdiv { \text { beach } }$

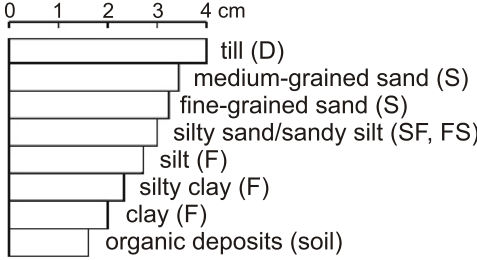

1 orientation of pebbles longer axis

$119 / 16$ orientation of faults

Fig. 12. Sedimentological log of the glaciolacustrine Wytowno Formation and the Dębina Till; profile I near Dębina (223.0 km) 


\section{PROFILE II}

[m]

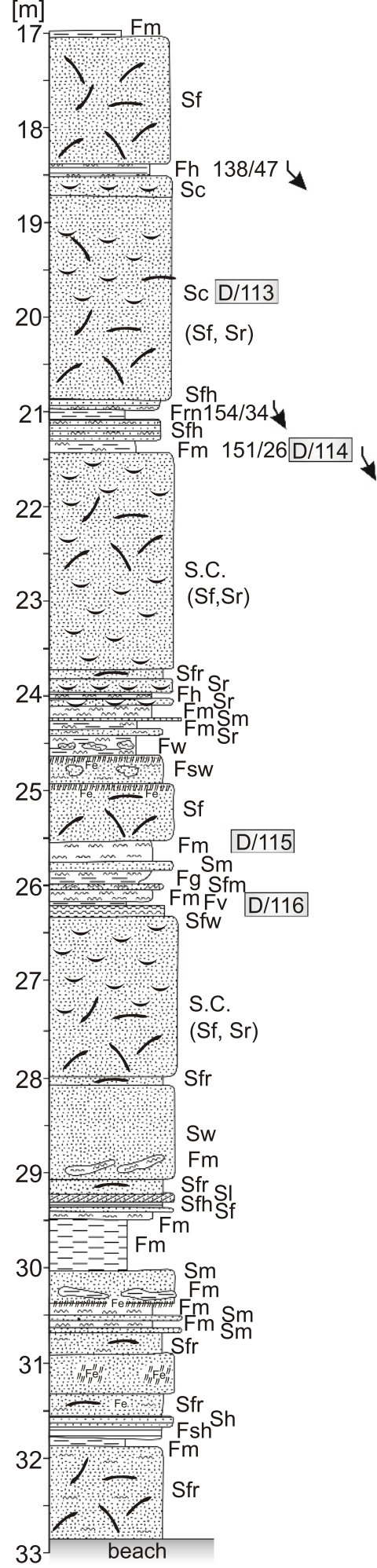

PROFILE III

$[\mathrm{m}]$

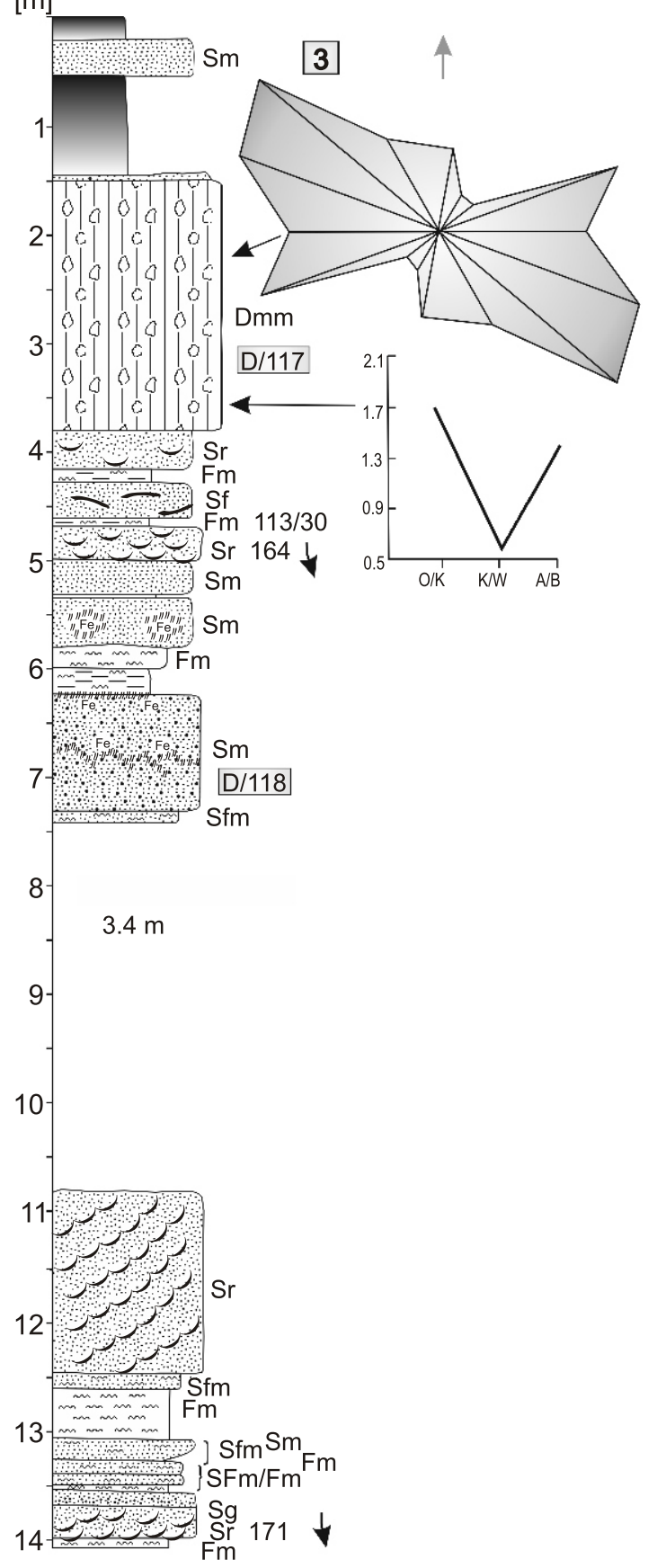

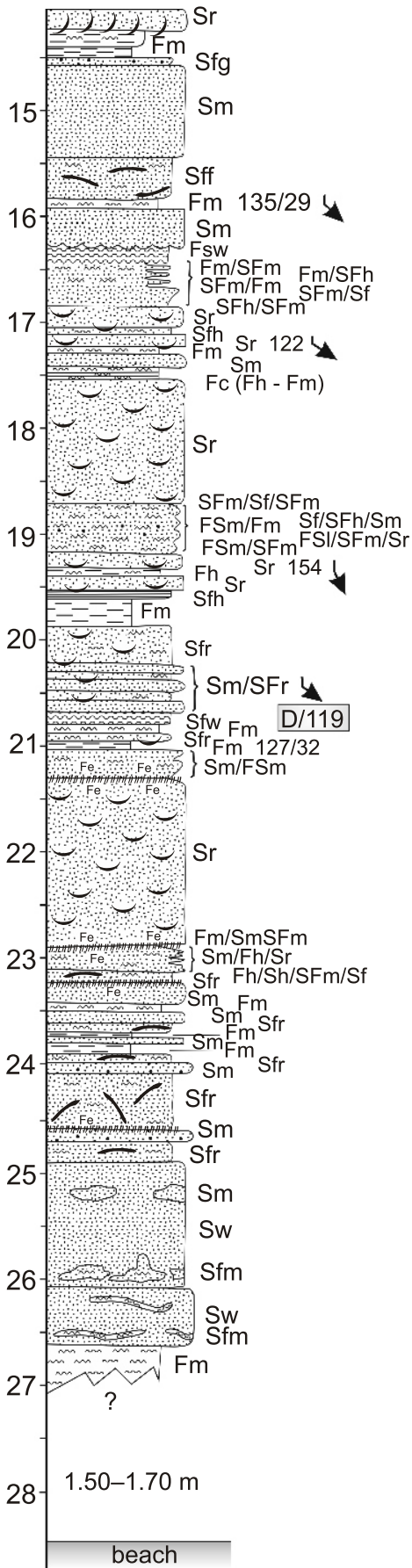

Fig. 13. Sedimentological logs of the glaciolacustrine Wytowno Formation; profiles II and III near Dębina (222.4 and $222.5 \mathrm{~km})$ Explanations as in Figure 12 


\section{INTERPRETATION}

Lower glaciodeltaic deposits are highly deformed. The sand-muddy series are glaciolacustrine in origin, and were probably accumulated in a delta zone. The origin of the diamictons is highly uncertain. They may represent flow tills, although it is greatly probable that they are parts of deformed subglacial tills.

The petrographic composition of the Poddabie Till is very similar to that of tills deposited during the Pomeranian Phase of the last glaciation in other areas of the Polish coast, e.g. in Trzęsacz (K/W 0.53-0.84; Krzyszkowski et al., 1998, 1999; Olszak et al., 2008, 2011; Krzyszkowski, 2010). Based on petrographic coefficients, this till represents the same glacial period. The upward-changing petrographic composition and orientations of gravel material in the till may reflect regional changes in the "advance" of the Pomeranian ice sheet, initially from the NE and finally from the NW. However, this interpretation certainly cannot be proved at the current stage of research It should be emphasized that samples containing more crystalline rocks (8 and 11) suggest the NW direction, while the remaining ones - NE. The other survey points of the NW directions (7 and 13) are rich also in limestones. These facts and the distinctly oriented material may suggest a glacial origin and be correlative with the Poddąbie Till. Probably, they could be formed by flaser lamination (overlapping breccia) in a subglacial zone (sands and muds; Henriksen et al., 2001; Jasiewicz, 2005).

Sandy diamictons of the Wytowno Formation represent probably flow tills resedimented from the Poddąbie Till or the Dębina Till. Deposition could occur either directly from the marginal zone (diamictons of large water bodies) or from icebergs (Houmark-Nielsen at al. 1990).

The presence of Pisidium obstusale lapponicum and $P$. lillieborgi and Gyraulus laevis, and the lack of Bithynia tentaculata in the Orzechowo Formation deposits suggest the Late Vistulian Glaciation (Alexandrowicz et al., 1989; Alexandrowicz, 1999). In the upper part of the sequence, the fauna is scarcer and the dominant species is Sphaerium corneum that may indicate growing eutrophication of the lake catchment basin. The lack of cold-loving species suggests milder climatic conditions (Moretti, 2011).

Palynological analysis has revealed the presence of mainly cold-loving flora (Fig. 10). The lacustrine pollen spectra are dominated by Pinus (48.1\%) and Betula (37.4\%), including $B$. nana, Juniperus and Salix. The content of Herbaceous varies from 23.3 to $36.1 \%$, including predominantly Poaceae, Cyperaceae and Artemisia (8.1\%). Less frequent are also Helianthemum, Hippophaë and Selaginella. The peat layer is characterized by a high content of herbaceous plant pollen (up to $57.1 \%$ ), represented exclusively by Cyperaceae and Poaceae. Pinus and Betula occur in smaller quantities, while Juniperus and Betula nana are sporadic. The deposits beneath the peat layer represent more severe climatic conditions. The flora species suggest a considerable number of open plant communities, including Artemisia, Helianthemum, Hippophaë and Selaginella. Marsz and Tobolski (1993) reported similar floral successions with peaty mud of lacustrine muds in Orzechowo, interpreting them as representing the BöllingAlleröd through the Younger Dryas.

Sand-muddy series directly above the peat may represent partly aeolian deposits, damaged dunes, or interdune deposits - laminated sands and muds. However, the presence of the coarse-grained sand layer may also suggest fluvial activity. The aeolian deposits are very poorly rounded, which suggests a lo- cal source of the sediment and its transport over short distances (Dullek and Olszak, 2013).

During investigation of profile I, we observed that the strata (younger) occupying a higher position show a more southeastward transport direction; precisely, the orientation was changing from NW-SE to NNW-SSE (Fig. 14). The measurements of the direction and dip of the strata were performed on mud and clay deposits at all sites (Figs. 12 and 13).

The evidence for the contact between the basin and ice is the presence of deposits that melted out from drifting ice rafts broken off the ice sheet terminus, referred to as dropstones. This can also be inferred from changes in the dip direction and dip angle of mud and clay layers, but in the instance of glaciodynamic deformation, the results of interpretation are ambiguous. As regards profile I, the changes in the directions recorded in ripple-mark structures and by stratal dips are similar, whereas in profile III, they are quite different, which may have been caused by different directions of meltwater flow. Deformation of these deposits is evidenced by large-scale faults at the site, and by smaller-scale faults observed at all sites investigated. The strongest deformation is found at profile I. This suggests that the deposits in this place were subjected to the greatest stresses.

\section{DISCUSSION}

The analysed section of the cliff is composed of limnoglacial deposits, overlain by glacial till, a series of dune sands, and a soil layer. The cliff probably exposes also older deposits - the Poddąbie Till, deposited before the ice sheet advance during the Gardno Phase, 16.8-16.6 cal ky BP (Wytowno Formation, Dębina Till and Gardno Till; Fig. 15; Krzyszkowski et al., 1998; Jasiewicz, 1998, 2005, 2007; Jasiewicz et al., 2005, Marks et al., 2016). The Poddąbie-type till, 5-13 m thick, observed in the lower part of the cliff at Dębina, is glaciotectonically stacked. The values of petrographic coefficients $\mathrm{K} / \mathrm{W}$, ranging from 0.55 to 0.85 , allow correlating the till with the basal till from Poddabie, assigned to the Leszno-Pomeranian Phase of the Vistulian Glaciation (Krzyszkowski et al., 1998, Marks et al., 2016). The Dębina-type till consists of two subunits. The lower one is represented by flow till deposited in an aqueous environment. Its gravel fractions are characterized by a high proportion of chalk, up to $30 \%$ of the whole sample. The upper subunit is represented by melt-out till, whose petrographic composition of the gravel fraction is characterized by a balance between the quantity of crystalline rocks and carbonates from the Baltic Depression (Bellec, 2010). Both till subunits of the Dębina-type till are correlated with the stages of Pomeranian ice sheet deglaciation, and their lack within ice-dammed lake deposits may be due to erosive action of river waters. The Gardno-type till was deposited in the form of thin flow layers, and it covers a zone of glaciotectonic deformation. The till is interpreted as the so-called Vistulian red till - the Gardno Till. The red till locally lies upon the light brown till, but also on silt deposits. It is formed either as a flow till with frequent interbeds of clay and sand, or as a massive till (Jasiewicz, 1998, 2005, 2007). In the cliff exposure, the tills range in thickness from several centimetres to $2 \mathrm{~m}$. Despite the complete lack of carbonates, probably due to post-depositional weathering, its petrographic distinctiveness in the fraction of $5-10 \mathrm{~mm}$ is highlighted by a very high proportion of alkali granites.

The reservoir at the shore was shallow, so the accumulation of the shallow-water type of delta, so-called the Hjulström Delta occurred which essential feature is the lack of steep slope 

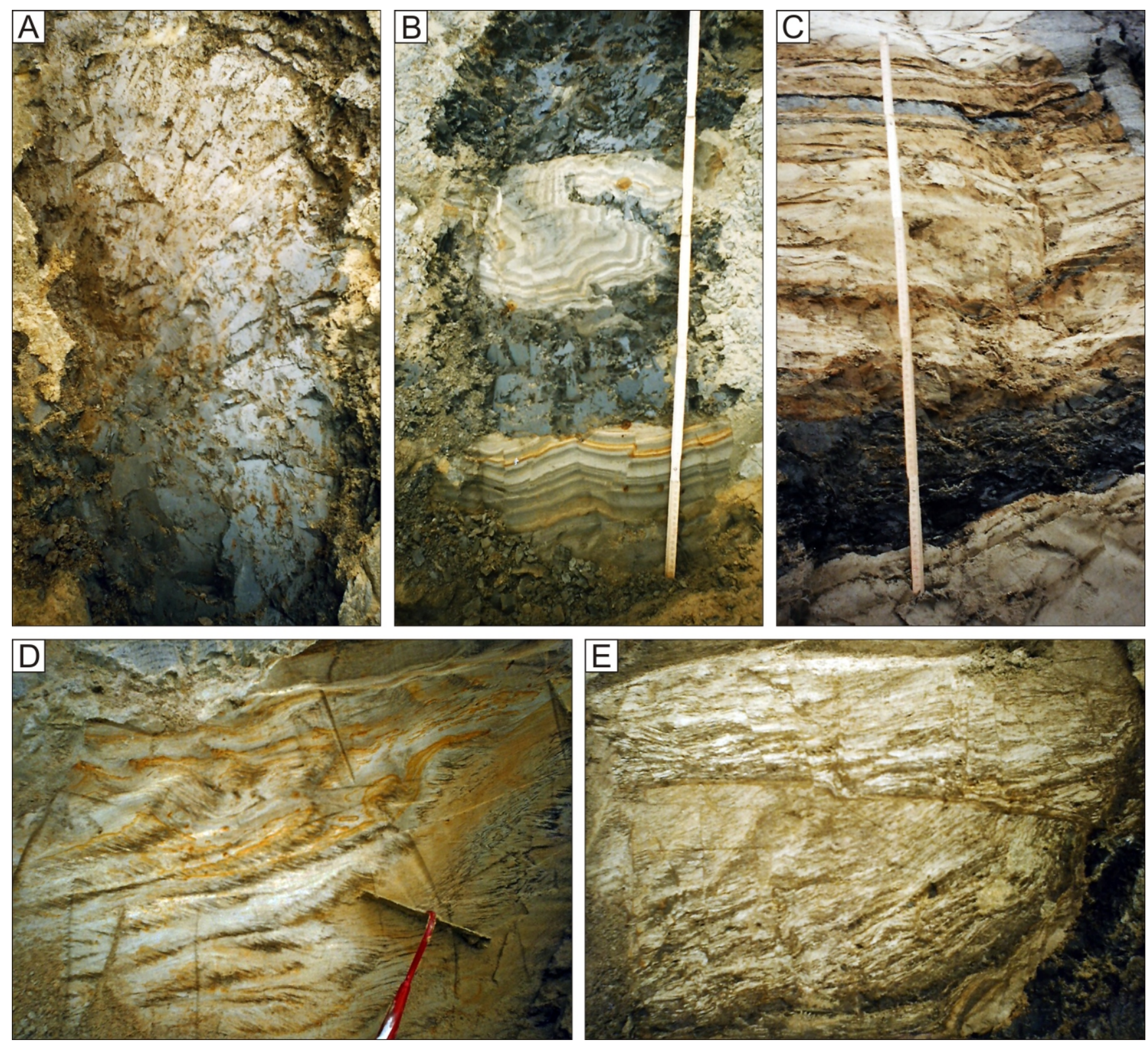

Fig. 14.

A - till, the contact between the upper brown till and the basal brown and grey till, profile I, 4.0-7.1 m (Fig. 12); B - laminated silty sand, separated by silty clay, (profile I), 8.2-9.1 m, bed D/104 (Fig. 12); C - sequence of deposits between 13 and $14 \mathrm{~m}$ in the investigated profile (Fig. 12), the lighter-coloured layers are sandy deposits, the darker ones are muds and clays; $\mathbf{D}$ - fine ripple-marked sand (with streaks of iron and heavy minerals), profile I, 9.1-9.95 m, bed D/105 (Fig. 12); $\mathbf{E}$ - deformation in the sandy mud bed, profile I, 13.2-14.0 m, bed D/111 (Fig. 12; Gostkowska, 1998)

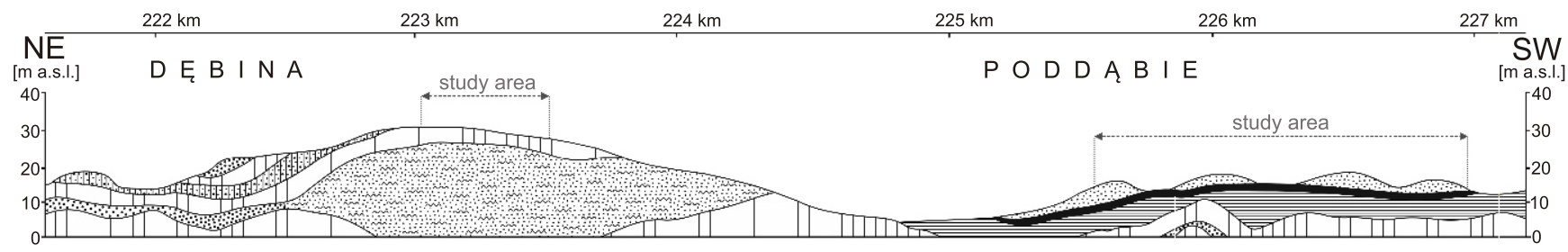

\begin{tabular}{|c|c|c|c|c|c|}
\hline $\begin{array}{l}2.1 \\
1.7 \\
1.3 \\
0.9 \\
0.5\end{array}$ & Gardno & $\square \| \mathrm{t}$ & 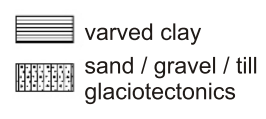 & $\begin{array}{l}\text { sand and gravel } \\
\text { silt, sandy silt and sand }\end{array}$ & $\begin{array}{l}\text { peat } \\
\text { aeolia }\end{array}$ \\
\hline $\begin{array}{l}2.1 \\
1.7 \\
1.3 \\
0.9 \\
0.5\end{array}$ & Dębina & $\frac{\forall}{O / K K W A B B}$ & & $\begin{array}{l}2.1 \\
1.7 \\
1.3 \\
0.9 \\
0.5\end{array}$ & Dębina \\
\hline $\begin{array}{l}2.1 \\
1.7 \\
1.3 \\
0.9 \\
0.5\end{array}$ & Poddąbie & & & $\begin{array}{l}2.1 \\
1.7 \\
1.3 \\
0.9 \\
0.5 \\
0.5 / K K\end{array}$ & Poddąbie \\
\hline
\end{tabular}

Fig. 15. Geological structure of the analysed section of the cliff 
(Hjulström, 1935). Its morphology is similar to delta plain (Kereszturia et al., 2014).

The shallow-water deltas are sloping, wide, and constitute a transitional link to the subaqueous cones, which can't be considered as deltas. Such deposits arise when sediment is deposited by the bottom currents (Zieliński, 2014).

\section{CONCLUSIONS}

The analysed deposits were accumulated in a proglacial basin. During the non-melting season, when there was no supply of material to the basin, muddy and clayey deposition took place from pelagic suspension, forming the characteristic lithofacies types. During ablation seasons, muddy and sand-muddy deposits were accumulated.

After recession of the ice sheet, the water level dropped in the basin, and the delta retreated. As the last icebergs had melted, the newly accumulated deposits no longer contained dropstone-type elements. Progradation and retreat of the delta could also occur as a result of minor oscillations of the ice sheet edge, when there was no contact between the basin and the ice.

The analysed deposits represent a deltaic environment and were accumulated on a Hjulström-type delta, which is gently sloping and shows no typical foreset unit. It is indicated by the lack of gravel and boulder fractions. The sedimentary basin was in contact with the ice sheet only sporadically, but generally did not interact with the active ice. Apart from some sequences there are no deposits derived from drifting ice rafts.

Ancknowledgments. Authors thank anonymous reviewers for their helpful and valuable comments. We also thank Prof. W. Florek and Dr. J. Krzymińska for their kindness and essential support.

\section{REFERENCES}

Alexandrowicz, S.W., Cichosz-Kostecka, A., Florek, E., Florek, W., Orłowski, A., Raczkowski, W., Zachowicz, J., 1989. The Evolution of the Słupia River Valley in the Late Vistulian and Holocene. Kwartalnik AGH, Geologia, 15: 5-218.

Alexandrowicz, W.P., 1999. Evolution of the malacological assemblages in North Poland during the Late Glacial and Early Holocene. Folia Quaternaria, 70: 39-69.

Bellec, V., Diesing, M., Schwarzer, K., 2010. Late Quaternary evolution of gravel deposits in Tromper Wiek, southwestern Baltic Sea. Journal of Coastal Research, West Palm Beach, Florida, 51: 173-186.

Czerniawska, J., 2004. Strefa przykrawędziowej sedymentacj osadów zastoiskowych i glacjalnych w północnej cześci kopalnego zbiornika $w$ dolinie dolnej Łupawy z okresu fazy gardnieńskiej (in Polish). In: Geneza, litologia i stratygrafia utworów czwartorzędowych (ed. A. Kostrzewski): 37-47. Wyd. Nauk. UAM, Poznań.

Dobrzyński, S., 1994. Stan dynamiczny strefy brzegowej morza na odcinku Ustka-Rowy w świetle badań litologicznych (in Polish). In: Konferencja Geologia i Geomorfologia Pobrzeża południowego Bałtyku, Słupsk (ed. W. Florek), 2: 82-88.

Dobrzyński, S., 1996. Geologia i geomorfologia Pobrzeża Południowego Bałtyku (in Polish). In: 45 Zjazd Polskiego Towarzystwa Geograficznego, Słupsk-Ustka, 18-21 września 1996. Przewodnik wycieczek: 157-168. Wyd. Uczelniane WSP Słupsk.

Dobracki, R., Krzyszkowski, D., 1997. Sedimentation and erosion at the Weichselian ice-marginal zone near Golczewo, northwestern Poland. Quaternary Science Reviews, 16: 721- 740.

Dziedzic, W., 1990. Geodynamika brzegu morskiego w rejonie Ustki (in Polish). Studia i Materiały Oceanologiczne, 55 87-106.

Dziedzic, W., Florek, E., Konarski, P., 1994. Stanowisko Ustka. Zmiany linii brzegowej na odcinku Ustka-Rowy w świetle map dawnych i współczesnych materiałów geodezyjnych. In: Konferencja Geologia i Geomorfologia Pobrzeża i południowego Bałtyku, Słupsk (ed. W. Florek), 2: 76-79.

Dullek, Ł.E., Olszak, I.J., 2013. Litologia osadów eolicznych pomiędzy Orzechowem a Ustką (in Polish). In: Geologia i Geomorfologia Pobrzeża i południowego Bałtyku (ed. W. Florek), 10: 51-65.

Gostkowska, M., 1998. Stratygrafia osadów na klifie w okolicy Dębiny (in Polish). M.Sc. thesis, Akademia Pomorska w Słupsku, Instytut Geografii i Studiów Regionalnych.
Hart, J.K., 1991. Proglacial glaciotectonic deformation and the origin of the Cromer Ridge push moraine complex, North Norfolk, England. Boreas, 19: 165-180.

Hart, J.K., Hindmarsch, R.C.A., Boulton, G.S., 1990. Styles of subglacial deformation within the context of the Anglian ice-sheet. The Earth Surface Processes and Landforms, 15: 227-241.

Henriksen, M., Mangerud, J., Maslenikova, O., Matiouchkov, A., Tveranger, J., 2001. Weischelian stratigraphy and glaciotectonic deformations along the lower Pechora River, Arctic Russia. Global and Planetary Change, 31: 297-319.

Hjulström, F., 1935. Studies of the morphological activity of rivers as illustrated by the river Fyris. Bulletin of the Geological Institute University of Uppsala, 25: 221-527.

Houmark-Nielsen, M., Kelly, M., Landvik, J., Sorby, L., 1990. The pre-Holocene Quaternary: lithostratigraphic and geomorphic evidence. In: Late Quaternary stratigraphy and glaciology in the Thule area, Northwest Greenland Meddelelser om Grønland: $8-20$.

Jasiewicz, J., 1998. Till stratigraphy and glaciotectonic style of the Gardno Phase end moraine. Excursion Guide: Field Symposium on Glacial Geology at the Baltic Sea Coast in Northern Poland, 13-19 September 1998, the Peribaltic Group INQUA Commission on Glaciation: 59-64.

Jasiewicz, J., 1999. Glaciotectonic structure of duplex (Gardno Phase end moraine, Dębina Cliff, west of Rowy) (in Polish with English summary). In: Ewolucja geosystemów nadmorskich południowego Bałtyku: 87-93. Bogucki Wydawnictwo Naukowe, Poznań-Szczecin.

Jasiewicz, J., 2001a. Vistuliańskie "gliny czerwone" i ich znaczenie stratygraficzne dla wydzielenia fazy gardnieńskiej (in Polish). In: Przemiany środowiska geograficznego nizin nadmorskich południowego Bałtyku w vistulianie i holocenie: $53-56$. Bogucki Wydawnictwo Naukowe, Poznań.

Jasiewicz, J., 2001b. Wpływ struktury glacitektonicznej na rzeźbę moreny czołowej na przykładzie form marginalnych fazy gardnieńskiej (in Polish). In: Przemiany środowiska geograficznego nizin nadmorskich południowego Bałtyku w vistulianie i holocenie: 57-61. Bogucki Wydawnictwo Naukowe, Poznań.

Jasiewicz, J., 2005. Stratigraphy of moraine tills and the glaciotectonic structure of the Gardno Phase end moraine (in Polish with English summary). The Poznań Society for the Ad- 
vancement of the Arts and Sciences, Prace Komisj geograficzno-geologicznej, 37: 122.

Jasiewicz, J., 2007. Weichselian red tills in the Gardno Phase End Moraine (Debina Cliff) - criteria for distinction, origin and stratigraphic position, and implications for the origin and course of the Baltic Ice Stream. Eiszeitalter und Gegenwart, 56: 295-310.

Jasiewicz, J., Czerniawska, J., Krzyszkowski, D., 2005. Stratygrafia osadów glacjalnych strefy marginalnej fazy Gardnieńskiej (Pobrzeże Bałtyku) na podstawie kryterium petrograficznego (in Polish). In: Plejstoceńskie i holoceńskie przemiany środowiska przyrodniczego Polski (ed. R.K. Borówka): 34-37. Szczecin.

Kereszturia, Á., Hargitaib, H., Postma, G., 2014. Encyclopedia of Planetary Landforms. Springer, New York.

Krzyszkowski, D., 1993. Pleistocene glaciolacustrine sedimentation in a tectonically active zone, Kleszczów Graben, Central Poland. Sedimentology, 40: 623-644.

Krzyszkowski, D., 1996. Climatic control on Quaternary fluvial sedimentation in the Kleszczów Graben, central Poland. Quaternary Science Reviews, 15: 315-333.

Krzyszkowski, D., 2010. Till stratigraphy, petrography and palaeogeography along the northwestern coastal region of Poland (in Polish with English summary). Biuletyn Państwowego Instytutu Geologicznego, 438: 51-92.

Krzyszkowski, D., Alexandrowicz, S.W., Kuszell, T., Dyrcz, M., Gostkowska, M., Grzegorczyk, B., 1998. Stratigraphy and sedimentary environments of the Late Pleistocene deposits, Excursion Guide: Field Symposium on Glacial Geology at the Baltic Sea Coast in Northern Poland, 13-19 September 1998, the Peribaltic Group INQUA Commission on Glaciation: 65-78.

Krzyszkowski, D., Dobracka, E., Dobracki, R., Czerwonka, J.A., Kuszell, T., 1999. Stratigraphy of Weichselian deposits in the cliff sections between Łukęcin and Niechorze, Balic Coast, northwestern Poland. Quaternary Studies in Poland, 16: 27-45.

Lisicki, S., 2000. Criteria for lithostratigraphic lithotypes of tills in studies of the Quaternary (in Polish with English summary). Przegląd Geologiczny, 48: 368-370.

Marks, L., Gałązka, D., Woronko, B., 2016. Climate, environment and stratigraphy of the last Pleistocene glacial stage in Poland. Quaternary International, 420: 259-271.

Marsz, A., Tobolski, K., 1993. Late Glacial and Holocene deposits in the cliff between Ustka and Potok Orzechowski mouth (in Polish with English summary). In: Geologia i geomorfologia środkowego pobrzeża południowego Bałtyku (ed. W. Florek): 201-250. WSP, Słupsk.

Miall, A.D., 1996. The Geology of Fluvial Deposits. Sedimentary Facies, Basin Analysis, and Petroleum Geology. Springer. Berlin, Heidelberg, New York.

Mojski, J.E., Pazdro, Z., Sylwestrzak, J.,1978. Objaśnienia do Mapy geologicznej Polski 1:200 000, arkusz Słupsk. Wyd. B. Inst. Geol., Warszawa.

Moretti, M., 2000. Soft-sediment deformation structures interpreted as seismites in middle-late Pleistocene aeolian deposits (Apulian foreland, Southern Italy). Sedimentary Geology, 135: 167-179.

Moretti, M., 2011. Soft-sediment deformation induced by sinkhole activity in shallow marine environments: A fossil example in the Apulian Foreland (Southern Italy). Sedimentary Geology, 235: 331-342.

Mycielska-Dowgiałło, E., 1995. Wybrane cechy tekstualne i ich wartość interpretacyjna (in Polish). In: Badania osadów czwartorzędowych. Wybrane metody i interpretacja wyników. Wydział Geografii i Studiów Regionalnych UW, Warszawa.
Olszak, I.J., Florek, W., Seul, C., Majewski, M., 2008. Stratigraphy and lithology of minerogenic deposits in coastal cliffs, middle section of the Polish Baltic coast. Landform Analysis, 7: 113-118.

Olszak, I.J., Florek, W., Seul, C., Majewski, M., 2011. Lithology of sediments and stratigraphy of glacial layers of some cliff sections on central and western Polish Coast. Geologija, 53: 1-9.

Petelski, K., 1975. On geological structure of a Gardno terminal moraine as seen in the cliff exposures between Dębina and Poddabie in West Pomerania (in Polish with English summary). Zeszyty Naukowe Wydziału Biologii i Nauk o Ziemi Uniwersytetu Gdańskiego, Geografia, 5: 169-180.

Petelski, K., 1976. Zaburzenia glacidynamiczne w spągu środkowego poziomu glin zwałowych w odsłonięciu klifu w pobliżu wsi Dębina na Pobrzeżu Zachodniopomorskim. Zeszyty Naukowe Wydziału Biologii i Nauk o Ziemi Uniwersytetu Gdańskiego, Geografia, 7: 87-96.

Petelski, K., 1985. Geological feature of Gardno lobe front moraine and end thought (in Polish with English summary). Biuletyn Instytutu Geologicznego, 348: 89-121.

Petelski, K., 1998. Geological structure of end moraine and terminal basin of the Gardno Lobe. Excursion Guide: Field Symposium on Glacial Geology at the Baltic Sea Coast in Northern Poland, 13-19 September 1998, the Peribaltic Group INQUA Commission on Glaciation: $56-58$.

Petelski, K., 2011. The influence of sub-Quaternary basement on the relief in the eastern part of the Pomeranian Lakeland, Poland. Annales Societatis Geologorum Poloniae, 81: 105-114.

Racinowski, R., Dobrzyński, S., Seul, C., 1992. Tendencje rozwojowe lądowej części strefy brzegowej morza między Rowami a Ustką w świetle badań morfologicznych i litologicznych (in Polish). Prace naukowe Politechniki Szczecińskiej, 459: 95-190.

Racinowski, R., Dobrzyński, S., Seul, C., 1993a. Wyniki badań morfologicznych i litologicznych lądowej części strefy brzegowej Bałtyku między Rowami a Ustką. In: Geologia i geomorfologia środkowego pobrzeża i południowego Bałtyku (ed. W. Florek): 169-179. WSP, Słupsk.

Racinowski, R., Dobrzyński, S., Seul, C., 1993b. Uziarnienie i skład mineralny osadów spoistych klifu między Rowami a Orzechowem (in Polish). In: Geologia i geomorfologia środkowego pobrzeża i południowego Bałtyku (ed. W. Florek): 155-167. WSP, Słupsk.

Rotnicki, K., 2001. Stratygrafia i paleogeografia Vistulianu Niziny Gardnieńsko-Łebskiej (in Polish). In: Przemiany środowiska geograficznego nizin nadmorskich południowego Bałtyku w vistulianie i holocenie: 19-31. Bogucki Wydawnictwo Naukowe, Poznań.

Rutkowski, J., 1995. Badania petrograficzne żwirów (in Polish). In: Badania osadów czwartorzędowych (eds. E. MycielskaDowgiałło and J. Rutkowski): 133-150. Warszawa.

Subotowicz, W., 1982. Litodynamika brzegów klifowych wybrzeża Polski (in Polish). Gdańskie Towarzystwo Naukowe, Ossolineum.

Tomczak, A., 1995. Geological structure of the coastal zone (in Polish with English summary). In: Geological Atlas of the South Baltic 1:500 000 (ed. J.E. Mojski). Państwowy Instytut Geologiczny - PAE, Sopot-Warszawa.

Zieliński, T., 2014. Sedymentologia. Osady rzek i jezior (in Polish). Wydawnictwo Naukowe UAM, Poznań.

Zieliński, T., Pisarska-Jamroży, M., 2012. Which features of deposits should be included in a code and which not? (in Polish with English summary). Przegląd Geologiczny, 60: 387-397. 